\title{
CORPORATE GOVERNANCE, CRITICAL JUNCTURES AND ETHNIC POLITICS: OWNERSHIP AND BOARDS IN MALAYSIA
}

\author{
NOR ZALINA MOHAMAD-YUSOF \\ Senior Lecturer in Accounting \\ Universiti Utara Malaysia, Malaysia \\ nzalina@uum.edu.my \\ DANTURE WICKRAMASINGHE \\ Professor of Accounting \\ University of Glasgow, UK \\ danture.wickramasinghe@glasgow.ac.uk
}

MAHBUB ZAMAN*

Professor of Accounting

University of Hull, UK

m.zaman@hull.ac.uk

Forthcoming in 2018 in Critical Perspectives on Accounting

(C) 2018. This manuscript version is made available under the CC-BY-NC-ND 4.0 license http://creativecommons.org/licenses/by-nc-nd/4.0/

Acknowledgements:

The authors gratefully acknowledge the constructive comments and suggestions on earlier versions of this paper from the editor (Yves Gendron) and two anonymous reviewers. The paper has also benefited from comments received, at the early stage of its development, from Richard Baker, Jim Haslam, Prem Sikka and participants at the APIRA Conference, CPA Conference, and the European Annual Congress.

*Corresponding author: Professor Mahbub Zaman, University of Hull, Business School, Cottingham Road, Hull, HU6 7RX, UK. Email: m.zaman@hull.ac.uk 


\title{
CORPORATE GOVERNANCE, CRITICAL JUNCTURES AND ETHNIC POLITICS: OWNERSHIP AND BOARDS IN MALAYSIA
}

\begin{abstract}
Quotas and affirmative policies are often implicated in debates on corporate governance. This paper examines critical junctures and the role of willful actors in mobilizing their ethnic and political positions to affect governance reforms in Malaysia since independence. We trace the trajectory of Bumiputera affirmative policy in shaping equity ownership and composition of boards of directors using historical institutionalism as a lens. We find ethnic politics has been an endogenous force resulting in Malay share of equity ownership rising from negligible levels to over 20 percent and almost half of the boards of directors of listed companies comprising of Malays. Our analysis shows that governance is a representation, as well as a manifestation, of how ownership and board structures are institutionally reproduced rather than a mere response to global isomorphic pressures.
\end{abstract}

Keywords: corporate governance; ownership; boards of directors; critical junctures; counterfactuals; contingencies; path dependency; Bumiputera 


\section{INTRODUCTION}

This paper examines how board composition and ownership structures are constructed and evolve in relation to ethnic politics that shaped affirmative policies in postcolonial Malaysia. Focusing on affirmative policies in reforming governance, it complements recent research on board diversity in different countries: countries differ in their approach to promoting diversity in the boardroom from mandatory quota approaches (e.g. Norway and Spain) to voluntary approaches (e.g., UK and Australia) (See Al-Shaer \& Zaman, 2016). The Malaysian context is, however, different: its equity ownership and representation on boards of directors were historically shaped by ethnic politics and resultant affirmative policies since the country's independence. Although ethnic politics in ex-colonies has been considered in critical/interpretive accounting research (Davie, 2005; Wickramasinghe \& Hopper, 2005; Efferin \& Hopper, 2007; Kim, 2008), its connection with affirmative policies and corporate governance has not been sufficiently explored. We try to fill this gap in the literature.

We draw on historical institutionalism ${ }^{1}$ that explores how ideas become pathdependent (dependent on past knowledge and trajectories) social practices under certain historical circumstances and political actions (see Thelen \& Steinmo, 1992; Thelen, 1999; Campbell, 2004). In particular, we use 'critical junctures' which is defined as the concrete, temporal process that lead to incremental changes in prevailing institutions. It is these temporal processes which inspire certain historic actors to take political opportunities to alter an institution's path-dependent trajectory. With a particular political agenda, such actors become willful social actors who can both challenge and change institutions (Collier \& Collier, 1991). It is these challenges and changes which we try to bring into the fore of the discussion of the institutional reproduction of corporate governance.

In Malaysia, Bumiputera ${ }^{2}$ (literally 'sons of the soil') developed a political agenda wherein willful actors addressed the issue of economic disparities between ethnic Malays and non-Malays. The notion of critical junctures helps us examine how this agenda was implicated in governance reform affecting equity ownership and representation on the boards of directors of Malaysian listed companies. We thus explore three questions: (1) what critical junctures gave shape to postcolonial ethnic-politics and in turn affected corporate board composition and ownership structures? (2) how did these critical junctures become pathdependent in reproducing board composition and ownership structures? (3) what counterfactuals and contingencies were present in relation to above changes? These questions led us to pursue a periodization analysis starting from 1957, 1970, and 1997, respectively. Our analysis reveals how Bumiputera's representation on boards of directors

\footnotetext{
${ }^{1}$ Historical institutionalism sits with institutional analyses which are enriched by three supplementary variants namely, rational choice institutionalism, historical institutionalism and sociological institutionalism (for a review, see Hall \& Taylor, 1996).

2 Bumiputera has three aspects here: primarily of the people (ethnic) (i.e. the indigenous people of Malaysia); secondly, a policy to further the benefits or interests of Bumiputera people; and, thirdly, an institution shaping corporate governance (CG) in the country. Malaysia's indigenous people comprise Malays and others termed 'natives' and 'aborigines'. Malays form a significant percentage of Bumiputera; therefore, the terms 'Bumiputera' and 'Malays' are used interchangeably herein. Non-Bumiputera refers to the immigrant Chinese and Indian.
} 
and their share of equity ownership was increased, despite global codes and practices of corporate governance.

The contributions of our paper to the literature are twofold. First, we show that corporate governance practices are not simply shaped by history and political contexts (e.g. Campbell, 2004), but involve an institutional process that passes through critical junctures, path-dependencies, and underlying counterfactuals and contingencies. We show that board composition and ownership structures are not given attributes but rather they become objects for institutional flux and opportunities, allowing willful actors to preserve or change those attributes through advancing affirmative policies. Second, we also contribute to accounting and ethnicity research in less developed countries (e.g. Wickramasinghe \& Hopper, 2005; Efferin \& Hopper, 2007). This embryonic stream of research has adopted cultural perspectives, political economy, and historical institutionalism broadly. To complement this, our paper focuses on willful actors' ethnically oriented agency roles implicated in how postcolonial affirmative policies are developed. Researching corporate governance from this angle is important as ethnic issues are perennial in postcolonial settings where social and institutional transformations occurred with ethnic clashes and compromises.

This paper proceeds as follows. Section 2 outlines our perspective on governance that is focused on critical junctures. Section 3 describes the context researched and the methods employed. Section 4 provides the periodization analysis, showing how board and ownership structures in Malaysian corporate governance were formed and reformed through critical junctures. Section 5 contains the discussion and the conclusion.

\section{GOVERNANCE: A HISTORICAL INSTITUTIONALISM PERSPECTIVE}

\subsection{The point of departure}

This paper complements research examining how corporate governance affects firm performance and accounting and auditing quality (Sloan, 2001; Bushman, Piotroski, \& Smith, 2004; Davis-Friday, Eng, \& Liu, 2006; Larcker, Richardson, \& Tuna, 2007; Gul, Zhou, \& Zhu, 2013; Mollah \& Zaman, 2015; Tee, Gul, Foo, \& Teh, 2017). Our analysis adds to this literature which is often based on shareholder perspective and tends to adopt positivist methodology. In contrast to a reliance on quantitative data and focus on testing the statistical significance between variables, our paper highlights the social and political underpinnings that reveal institutional explanations of governance practices (Huse, 2005; Turley \& Zaman, 2007; Tremblay \& Gendron, 2011; Zaman, Hudaib, \& Haniffa, 2011). For example, Sloan (2001) explores how organizing accounting functions through corporate governance practices enhances firm performance but does not consider the influence of contextual ramifications (see Brennan \& Solomon, 2008). Our analysis of governance reform also augments research which adopt stakeholder perspectives (e.g. Hill \& Jones, 1992; Coyle, 2007; Solomon, 2007), use alternative theories, and seek to broaden the scope of governance research and examine 
implications for accountability and the wider society (see Brennan \& Solomon, 2008). ${ }^{3}$ We add to this commendable development in the literature by adopting a historical perspective to explore the formation, development and underlying policy issues of governance.

Our focus on exploring how governance ideas emerge, evolve, and change through institutional and social processes, and through political and historical struggles, complements among others, the works of Efferin and Hopper (2007), Uddin and Choudhury (2008) and Yonekura, Galhofer and Haslam (2012) who focus on developing country contexts. Also, while corporate governance reform and structures in Malaysia has been the subject of prior research (e.g. Haniffa \& Hudaib, 2006; Salleh \& Stewart, 2012; Fung, Gul, \& Radhakrishnan, 2015; Mat Zain, Zaman, \& Mohamed, 2015; Tee et al., 2017), we add to them by drawing on recent advancement in the historical intuitionalism literature to unpack the processes and struggles affecting ownership and board structures in Malaysia.

\subsection{Towards critical junctures}

Attention to wider institutional context is particularly important in critical-interpretive research on corporate governance (Turley \& Zaman, 2004). Historical institutionalism emphasizes how institutions emerge and become path-dependent providing knowledge and trajectory for social practices (Thelen, 1999). To this end, researchers have analyzed (comparatively) the emergence of, and processes in, different institutions (i.e. ideas, practices, and institutional arrangements) and interpreted institutions in terms of their trends in macro contexts (Hart, 1994; Hansen, Johnson, \& Unah, 1995). These researchers argue that institutions are historical constructs that eventually become path-dependent practices: once the institutions have been established, people 'blindly' follow them, regardless of their efficiency and effectiveness. Hence, most historical institutionalists (e.g. Campbell, 2004) largely neglected how path-dependent practices change. A focus on critical junctures attempts to address this.

Critical junctures are situations involving concrete, temporal (and political) processes that can lead to subtle and gradual change rather than abrupt and wholesale transformation of institutions (Thelen, 1999; Capoccia \& Kelemen, 2007; Mahoney \& Thelen, 2010; Soifer, 2012). Temporal processes here consist of historically important political actions involving arguments and agitations against prevailing institutions and offer alternatives to those institutions. In studying these critical junctures, researchers pay attention to two main developments. First, the "change-permitting properties" (Mahoney \& Thelen, 2010, p. 3) in these temporal processes: they may be certain social and cultural forces (e.g. class, caste, ethnicity or religion) and contradictions with established institutions and practices (e.g. challenging the colonial forms of governance upon independence). For example, if a particular ethnic group was marginalized during colonial era (as in our case), post-independent movements agitate to regain its social acceptance so that ethnicity becomes a change

\footnotetext{
3 Theories used include stakeholder theory (Wheeler \& Sillanpää, 1997), resource dependency theory (O'Connell, 2007), institutional theory (Parker, 2007), Weber's rationality ideas (Uddin \& Choudhury, 2008), sociological and political theory perspectives (Sikka, Puxty, Willmott, \& Cooper, 1998; Gendron \& Bédard, 2006). See Wickramasinghe and Alwattage (2007) for a review of various theories.
} 
permitting property in restructuring governance and administrative apparatuses. Although such change permitting properties would not materialize and subsequent changes would not occur immediately, political maneuvers towards such change can be organized through gradual social movements, sporadic events and incidents. When using "critical junctures" as a perspective, one can then trace these events and movements to articulate how changepermitting possibilities are created, debated and, in turn, established, despite struggles and difficulties.

The second development concerns understanding actors' roles in such political movements. Actors who mobilize their political motives through the consent and support of large groups of people are called 'willful actors' (see below). This helps a 'will-to-power' develop that can affect the 'change-permitting properties' in a social and historical context. Generally, these properties are self-enforcements that drive institutional change, although the critical junctures literature combines this with willful actors' agency which can foster change in subtle and incremental ways. That said, critical junctures seek path-dependent effects broadly and focus much on temporal processes and willful actors' actions. While mainstream historical institutionalism explores 'lock-in' effects leading to taken-for-granted assumptions, critical junctures explore possibilities of incremental change evolving over years through "slow-moving causal processes" (Mahoney \& Thelen, 2010, p. 3). In other words, critical junctures look for path-dependent effects broadly while focusing much on temporal processes and willful actors' actions.

Consequently, researchers have revisited the structure-agency debate to combine path-dependence arguments with critical junctures. Here, they consider path-dependence as a structured institution that constrains institutional change, while critical junctures prompt debate and change established institutions through an 'institutional flux' whereby willful actors confront alternative institutional arrangements (see Collier \& Collier, 1991). Such a situation is 'critical' because various alternatives are still available for ongoing scrutiny. Hence, critical junctures operate through counterfactuals - 'what if' analyses about the choices not selected. These analyses are subject to political debates, (media/broadsheet) critiques, and resultant power struggles, and they challenge the constraints of the pathdependent nature of historical institutions. There is often room for contingencies as well those unexpected occurrences that cannot be explained 'deterministically' or 'probabilistically'. Contingencies can demand certain actions from willful actors when tackling issues in temporal processes. Thus, formulation of policy affecting corporate governance structures and practices is not always rational but is context-dependent, pragmatic and, in turn, variable (Flyvbjerg, 2001).

\subsection{Power as a supplementary instrument}

The above understanding also enables us to articulate how power - one's ability to carry out his/her own will in a social relationship, despite resistance (Weber, 1978) - is linked to critical junctures and underlying historical analyses. As Hay and Wincott (1998) observed, in historical institutionalism, willful actors' beliefs and their (political and cultural) ideologies become 
crucial in an institution's emergence and development. Institutions are a result of struggles between dominant interests and ideologies manifesting concrete actions in temporal processes creating politics and policies: "politics creates policies, policies also remake politics" (Skocpol, 1992, p. 58). Such struggles and their consequences involve both path dependence and critical junctures: path dependence represents constraining forces based on historical trajectories, traditions, and cultures, while critical junctures point to phases of institutional flux, as we mentioned earlier (Collier \& Collier, 1991; Ertman, 1997; Katznelson, 2003).

Institutional flux then creates opportunities for actors to mobilize their willfulness only in virtue of their 'will-to-power'. For Clegg (2006), this institutional flux is a relational space where history, power, and imaginations are defining principles. In other words, history is made - as a tradition or institution - based on will-to-power and the capacity to conceive a difference (imagination). How this happens in an institutional flux can be studied when focusing on critical junctures - those concrete, temporal processes and willful actions that conceive a difference because willful actors make history through powerful (ethnic-based, in our case) involvement. In doing so, they "imagine" and hold an ideology about a state of end results (in our case, Bumiputera domination).

\subsection{History and governance intertwined: three interrelated propositions}

So, how do critical junctures help us understand board composition and ownership structures in Malaysian listed companies? In tackling this question, we follow three interrelated propositions as our epistemological guide:

1. Agency proposition: Following actors and their willful actions in relation to historical phases in a postcolonial context can help one understand how actors mobilize their willingness to preserve and maintain certain values such as ethnicity, traditional cultures, and nationalistic motives. It can also assist in exploring the social and political realities behind taken-for-granted views on social practices such as corporate boards and ownership structures. Our use of critical junctures can help uncover how and why certain willful actors are implicated in the historical construction of corporate governance.

2. Power proposition: Power as an ability to carry out one's "will" is an important axis that hinges on actors and their actions which make history. Engagement to make certain ideologies overwhelmingly dominant and attractive will be possible when actors can imagine making a historical difference. When previous path dependencies can be challenged, new path dependencies can be introduced, and history can be remade using the power of those with political motive, or will-to-power. Previous path dependence can only be questioned through power relations.

3. Historical proposition: In relation to 2 above, an alternative historiography becomes useful. As opposed to the traditional accounting historiography which emphasizes 
the capacity to reveal the truth about the past based on verifiable historical facts, this alternative historiography can take the genealogists' approach which examines conditions, circumstances and acts of will as well as counterfactuals and contingencies to show how history is made into a strange present (Richardson, 2008).

\section{DATA AND ANALYSIS}

\subsection{Data}

As has already been mentioned, we explore corporate governance as a politically constructed practice that has experienced much debate during its evolution on diverse issues, ranging from how initial conditions developed into path dependence, through the critical junctures of institutional flux, and to self-reinforcements for institutional reproduction or change. To explore the historical process in this manner, as many accounting historians do (see Richardson, 2008), we collect data largely from archives such as legislative publications, monographs, and local articles. We use this data to trace events that were possibly politically and socially critical in the evolution of Malaysian corporate governance practices from preindependence to recent times. We also use material from the public domain, such as speeches by politicians and books by influential figures. Furthermore, we rely on government websites, press releases, government officials' speeches, and international organizations' reports.

When a mountain of materials accumulated, we revisited historical institutionalism which inspired us to reconcile the periodization analysis with critical junctures. This allowed us to re-read and analyze the materials to better understand how concrete, temporal processes inform certain periods in history from the late 1950s (see below). This process led us to provide evidence on how critical junctures came about, how certain willful actors were involved in each of the events, and how contingencies and counterfactuals were implicated in the making and re-making of historical phases.

\subsection{Analysis}

Our periodization analysis identified three historical phases that created critical junctures for willful actors to exploit opportunities for establishing the Bumiputera institution. This preliminary analysis enabled us to produce our historical narrative (Fairclough 2003; Leitch \& Palmer, 2010) of how the trajectory of Bumiputera institution influenced governance practices. Throughout this narrative, we focus on events and incidents in critical junctures to trace how equity ownership and board structures in listed companies, including GovernmentLinked Companies (GLCs), developed since independence in 1957. The narrative developed through detailed reflections on secondary sources and writing and re-writing processes to position the data within the theoretical framework (Ahrens \& Chapman, 2006). The resultant narrative illustrates how critical junctures provide not only a way of understanding board representation and ownership structures but also an alternate historiography that shows how history is discursively made (Richardson, 2008). 


\section{FINDINGS AND NARRATIVES}

We have identified three historical phases (see Figure 1$)^{4}$ : (i) the country's independence in 1957; (ii) the New Economic Policy (NEP) launched in 1970; and (iii) the 1997/98 Asian economic crisis. Although this periodization may also represent a structural evolution in the Malaysian socio-economic and political landscape, we use "critical junctures" which helps us to understand how Bumiputera affected the reform of corporate governance in Malaysia. In Figure 1, the left-hand side panel represents these critical junctures while the right-hand side panel shows Bumiputera mechanisms and their effects on corporate governance. Inferences about Bumiputera's impact on ownership are made via the progress towards target percentage of equity ownership as stated in the affirmative policy of Bumiputera.

\section{[Insert Figure 1 about here]}

\subsection{Phase 1: Willful actors - in the making of Bumiputera institution}

As discussed earlier in Section 2, critical junctures create opportunities for willful actors to alter trajectories - in our case, that of corporate governance in postcolonial Malaysia. These actors are willful because they hold an agenda inspired by a political (and cultural) ideology and because they are engaged in continuous politics and struggles to achieve this agenda. Their engagement gave rise to 'will-to-power' for challenging the political ideology underpinning the existing colonial institutions that had played a path-dependent role (Mahoney \& Thelen, 2010). Willful actors' roles became historic because they exercised their will-to-power in an institutional flux towards 'change-permitting' temporal processes - in other words, critical junctures (Thelen, 2004). This section shows how the Bumiputera institution emerged through a temporal process wherein willful actor debated, propagated, and, in turn, sustained this institution, despite certain counterfactuals and contingencies.

Bumiputera institution emerged representing both an outcome of a temporal process through historical junctures and a series of means to such outcomes. The temporal process goes back to pre-independent Malaysia (then Malaya), when opportunities emerged for willful actors to do some 'historical work'. Two related critical junctures are central here: (1) the rejection of the British idea of the Malayan Union in the post-World War 2 period; and (2) Britain's declaration of the country's independence in 1957 and the subsequent promulgation of a new constitution (see below). These critical junctures are interrelated as native Malays opposed the union idea while the declaration of independence provided an opportunity for them to pursue their opposition.

Malay opposition was linked to a gradual shift in power structure. The prevalent governance structure for centuries was the rule of the Sultans. ${ }^{5}$ Since colonization, the power

\footnotetext{
4 Most researchers in the social sciences followed this method of periodization analysis in numerous comparative historical analyses (Lieberman, 2001; Perusek, 2002).

5 Malaysia is now a constitutional monarchy and the Head of the State (Yang di-Pertuan) is elected, from among themselves, by the nine Sultans (hereditary rulers). As observed in the Economist (February $3^{\text {rd }}$, 2017, How powerful are Malaysia's Sultans'), "Although more than 40 countries retain a monarch of some sort, Malaysia's system is probably the world's oddest. The country has nine sultans, who as well as reigning ceremonially in their own states take it in turns to serve five-year terms as Yang di-Pertuan Agong, the head of state of the entire country. The sultans meet three
} 
of Sultans declined as the British established new administrative structures to run the state. Later, the Sultans had to obtain advice from the British and to act accordingly on all matters except those concerning Malay religion and customs (Yong, 2004). The Malays' political power was further weakened when the British introduced a migration policy in late $18^{\text {th }}$ century that allowed many Chinese and Indian workers to enter the country. ${ }^{6}$ By 1921 , the number of migrants almost equaled the Malay population and some policies disadvantaged the Malays both politically and economically. ${ }^{7}$ Such developments led Malays to agitate politically. In response, the British recognized the Malays as the country's original people, but this was not deemed favorable enough (Horii, 1991) ${ }^{8}$ because elite Chinese capitalists enjoyed economic prosperity while Malays had limited opportunities in both social and economic spheres (Yong, 2004).

However, a critical juncture transpired during World War 2 when the Japanese briefly occupied Malaya until August 1945. British return to power in September 1945 brought a proposal for a Malayan Union. At that time, Malaya comprised nine legally sovereign states, and the Malayan Union scheme proposed amalgamating them (except Singapore) into a unitary state and to guarantee equal rights for everyone, including Chinese and Indian immigrants. However, Malay people resisted and in 1948 the Federation of Malaya Agreement was signed by Malay Sultans and the British government. This Agreement became a critical juncture - a historical moment that restored Malays' special position. ${ }^{9}$ It has implications for path dependence which are important for our analysis. We discuss these below.

\subsubsection{An initial temporal act on critical juncture: Rejection of Malayan Union}

The Union proposal contained three radical provisions (Horii, 1991): (1) abolishing the Malay Sultanate system; (2) ensuring equal rights (of political and cultural participation) for the whole population; and (3) granting citizenship to all permanent residents. Resistance to this came from Malays' belief that the Sultans were forced into accepting the Malayan Union, the Sultans would lose their political power and become mere social and religious leaders, and

\footnotetext{
times a year and are considered guardians of the culture and religion of the ethnic-Malay majority, though they have little formal authority."

${ }^{6}$ The influx of Chinese and Indian immigrants had increased the population of Malaya from 550,000 in 1850 to about 2.4 million in 1911. In 1931, the combination of 1.6 million Chinese and 0.6 million Indians had already exceeded the Malay population of just under 2.0 million (Khoo, 2005). In 2017 the population in Malaysia is estimated at 32.0 million: 28.7 million are citizens and 3.3 million are non-citizens. The 28.7 million Malaysian citizens consist of $68.8 \%$ Bumiputera, 23.2\% Chinese, 7\% Indians, and 1\% others (Mahidin, 2017).

7 These include the British 'divide and rule' policy which separated the Malays from the immigrant communities physically and disadvantaged the former economically (Jesudason, 1989).

${ }^{8}$ For example, the British introduced the Rice Land Act to protect Malays' land. However, this prohibited Malay peasant from cultivating any crop other than rice on Reserve land, which prevented them from engaging in modern economic activities (Lim, 1985).

${ }_{9}^{9}$ The phrase "a historical moment that restored Malays' special position" refers to the fact that the signing of Federation of Malaya Agreement (after the dismantling of Malayan Union) restored Malays' special position in the country as the original people of Malaya. They enjoyed this special position during British colony as the British had recognised them as the original people of Malaya, while Chinese and Indians were recognised as immigrants. However, under Malayan Union scheme, all ethnicities / populations were considered equal (Chinese and Indian were eligible for citizenship of Malaya). Hence, when the Federation of Malaya Agreement was signed in 1948, the Sultanate system was restored and Malays enjoyed their special status, as Bumiputera again.
} 
granting citizenship to immigrants would jeopardize Malays' special position in society. In short, Malays alleged that the proposal threatened their identity (Sopiee, 2005).

A key willful actor in this resistance was Dato' Onn Jaafar, a well-known elite (but not Royal) with an English education, who promoted unity among the Malays and influenced the Sultans to reject the Malayan Union proposal. Consequently, seven members of the Malayan Union Advisory Council refused to serve in the legislature and Onn founded the United Malays National Organization (hereafter UMNO) to represent all Malays (Sopiee, 2005). Despite the resistance, the Malayan Union was inaugurated on April 1, 1946, but on May 11 UMNO was reconstituted with Onn elected, with the backing of the Sultans, as its first president. The Malay nationalists acted in concert with the Old Malayans ${ }^{10}$ and the Rulers. This coupled with increased opposition to British policy from British officials in Malaya meant the Malayan Union survived only for less than two years. It was dismantled in February 1948 and the British signed the Federation of Malaya Agreement with the Sultans and the UMNO. The willful actor's role was thus historically significant in this critical juncture.

The phase of rejecting the Malayan Union involved heightened contingencies for Malay states. The British had the option to either continue with the Malayan Union scheme or to submit to Malay demands. The former would significantly diminish the Malays' political power; also, equal citizenship would remove Malays' special positions in the states. A plausible consequence was continued resistance from the Malays and withdrawal of their support. As the British relied on Malays to oversee rural areas, Malay opposition would jeopardize British control there. Thus, under these contingent circumstances, the British abolished the Malayan Union and signed the Federation of Malaya Agreement and transferred political power to the Malays. More political power later enabled the Malays to implement policies to pursue their economic interests and affect corporate governance reforms.

\subsubsection{A Revitalization of Critical Junctures: Effect of independence on governance}

Independence in 1957 became another critical juncture for the emergence and development of the Bumiputera institution and subsequent effects on governance structures. Independence marked the handing of political power to the then National Coalition (Alliance) ${ }^{11}$ and also the successful negotiation by UMNO to preserve Bumiputera interests. The Alliance made a series of important deals, or a social contract: bargaining between the Malays and non-Malays to preserve the Malays as the states' original people and granting citizenship to Chinese and Indian immigrants (Thomas, 2007). Consequently, the immigrants accepted the Bumiputera's special position and in exchange the Malays guaranteed citizenship for non-Malays and secured their economic interests. This social contract was later reflected and reinforced in the 1957 Constitution of Malaya.

\footnotetext{
10 The Old Malayans are the Malay people who resided in Great Britain during that period.

11 An alliance established between three political ethnic-based parties representing their respective ethnicity: UMNO representing the Malays (headed the alliance); the Malaysian Chinese Association (MCA) - representing the Chinese; and the Malaysian Indian Congress (MIC) - representing the Indians.
} 
Although political power was transferred to the Alliance, the UMNO remained dominant and pursued Bumiputera's economic interests and sought means to increase their representation on boards of directors and share of equity ownership. The critical juncture of independence therefore secured Bumiputera's special constitutional rights and the Malays' power, i.e. both independence and the constitution placed Bumiputera's 'institutional arrangements' for many path dependencies, therefore marking a starting point for the exercise of Malay political power and pursuit of interests.

The critical juncture embedded in independence evidently changed the governance landscape by guaranteeing the Malays' representation on corporate boards. In other words, independence became a 'change-permitting property' that put Malays on corporate boards despite their limited investment and experience (Mohamad, 1970). This development led to more 'will-to-power' for the Malays: they developed close relationships with Chinese businesses; the Malayanization of British business interests followed; and Malayan investment and trading companies emerged (ibid). However, the Malays' involvement in the economy remained minimal. In 1969, their equity ownership stood at only $1.5 \%$ (see Figure 2), which also reflects their ownership of other assets such as land and buildings (EPU Economic Planning Unit, 1971, pp. 39-41). Also, their representation on corporate boards of directors was not significant (see Figure 3a) and foreigners continued to monopolize the economy and hence foreign directors dominated boards. Nevertheless, Bumiputera representation appears significant when contrasted with their shareholdings. For example, in 1969 , about $10 \%$ of directors in pioneer companies ${ }^{12}$ were Malays although the appointments were confined to a few influential Malays, e.g. $60 \%$ were former bureaucrats and/or politicians (Lindenberg, 1973, cited by Lim, 1985).

\section{[Insert Figures 2, 3a, 3b and 3c about here]}

\subsubsection{Contingencies and counterfactuals}

We find that it was the ethnic orientation of post-independent Malaysian politics that, through the Bumiputera institution, infused an ideological rationality into board representation and ownership structure. While the rejection of the Malayan Union in 1946 and independence in 1957 materialized critical junctures, this ethnic orientation triggered multiple political powers for the Malays. Accepting the Malayan Union would not have given the Bumiputera any special rights or privileges because this involved establishing equal citizenship. Independence came through the Federation of Malaya Agreement, which inspired Malays to pursue social prominence. The Malayan constitution protects this privilege; hence, these contingencies were subtle reactions from Malays through which they secured some notable powers compared with the Chinese in Malaysia.

\footnotetext{
${ }^{12}$ Pioneer status may be granted to companies participating in promoted activity or producing a promoted product. The power to determine what is a promoted product or activity lies with the Minister of International Trade and Industry. The list includes manufacturing, agricultural, hotel and tourism sectors.
} 
Moreover, willful actors carefully thought of counterfactuals ('what if' analyses) to address unintended consequences. For example, rejecting the Malayan Union not only prevented the transfer of ceremonial political power from the Sultans to the British but also strengthened the Sultans' position and - through their newly formed political engine, UMNO - Malays' political power. Rejecting the Malayan Union, the declaration of independence of Malaya, and the country's constitution yielded the path-dependent Bumiputera institution, which later affected Malays' representation on corporate boards of directors and share of equity ownership.

\subsection{Phase 2: Power as an additional mechanism}

The neglect of Bumiputera's economic interest gave rise to another critical juncture. The neglect came from the institution's embryonic form and underlying political struggles not being strong enough to organize interests that brought sufficient power to influence Bumiputera representation on corporate boards of directors and share of equity ownership. Hence, as Phase 1 suggests, institutional building was incomplete. Phase 2, however, significantly influenced Bumiputera ownership and board representation, and the institution developed in certain ways. This section discusses how it happened.

\subsubsection{Post-Independence - Economy without Intervention}

Post-independent Malaysia contained ethnic, religious, and language divisions. The economy was largely controlled by foreigners. ${ }^{13}$ Although the constitution spelled out Bumiputera's special position, including preferential treatment regarding government roles, access to educational scholarships, and the allocation of business licenses, it made little difference to the Bumiputera people. Malays still found it difficult to prosper economically: in $197064.8 \%$ of Malay households lived below the poverty line compared with $26.0 \%$ of Chinese and $39.2 \%$ of Indian households (EPU, 1976, p. 180). UMNO's political power was still weak as the prime minister, Tunku Abdul Rahman, was reluctant to favor Bumiputera lest it jeopardized Chinese economic interest.

As White (2004a) notes, like many Alliance leaders, Tunku Abdul Rahman came from a privileged class and promoted the multi-racial, free-enterprise, and pro-British vision of governance. The Alliance was considered heirs of the colonial rulers while British companies dominated the economy. Although UMNO leaders were in the cabinet, its influence was limited: it depended on the MCA which had significant influence in government circles. MCA mitigated the efforts of younger Malay leaders who threatened MCA's interests. Consequently, as White (2004b, p. 393) notes, despite UMNO's commitment to advancing the kampung (Malay villagers), no scheme was introduced that increased Malays' share of the economy. Meanwhile, MCA's political power helped prevent excessive bureaucratic interference in private businesses.

13 Foreign presence was most pronounced in the manufacturing sector where, in 1970, it controlled almost $60 \%$ of capital in manufacturing (Jesudason, 1989, p. 60). 
Nevertheless, the importance of the Bumiputera's economic interest was made explicit by certain young Malay nationalists within UMNO who championed the Malay case. By the mid-1960s, Malay businessmen started to pressure the government through their connections with political and administrative elites. The First (1965) and Second (1968) Bumiputera Economic Congress were crucial here. ${ }^{14}$ As Khoo $(1987$, p. 112) notes, a delegate said: "If the Malays have no stake in this country . . . [it] is certain that the non-Malays will find it difficult to carry on their economic activities in peace and security." Quoting from the first Congress, Lim (1985, p. 260) also notes: "If Bumiputeras do not own their companies or do not share the ownership of Malaysian companies, then this policy is a failure." Both congresses highlighted Malays' unhappiness with their lack of representation on corporate boards, which was particularly criticized in the second Bumiputera Economic Congress (Lim, 1985). Several proposals were thus developed which included: (i) giving training opportunities to develop Bumiputera expertise; (ii) strategizing Bumiputera expansion in the economy; (iii) solving the problems of Bumiputera businesses; and (iv) ensuring pioneering companies reserve at least $10 \%$ of ownership for Bumiputera (Jesudason, 1989). These efforts did not significantly affect governance structures, especially board representation and equity ownership, because while young Malay nationalists promoted the Bumiputera institution UMNO elite leaders were focused on country's economic stability (Khoo, 1987). The young Malay nationalists had insufficient power to affect institutional change. The ethnic clash that occurred on May 13, 1969 was, however, a critical juncture that ushered in significant change.

\subsubsection{The May 13, 1969 ethnic clash: another critical juncture}

In May 1969, perceived economic disparities caused an ethnic clash between Malays and the Chinese after the country's general election which gave Chinese candidates from the opposition party significant parliamentary power (Reid, 1969). Several important events followed. First, a state of emergency was declared and parliamentary democracy was suspended for about 21 months. Second, a new Malay-dominated National Operations Council was created to coordinate executive actions under the leadership of the then deputy prime minister, Tun Abdul Razak, because the prime minister, Tunku Abdul Rahman, had lost credibility with the Malays (Jesudason, 1989). With the formation of National Operations Council, Tunku was sidelined and gradually lost political power while Tun Abdul Razak had "virtually unlimited power to rule by decree" (Funston, 1980, p. 212). Several important political figures emerged, including Mahathir Mohamad who proposed the politico-economic solution of "constructive protection"15 (Mohamad, 1970, p. 31). He deemed racial equality a prerequisite for racial harmony and national unity. Pressures also mounted as the young group of Malay leaders outside the cabinet proposed recommendations for the new cabinet,

\footnotetext{
14 The congresses' objectives were to generate interest among the Bumiputera to participate in commerce and industry - by providing facilities for training those interested in the two fields - and to find ways and means of securing those objectives.

${ }^{15}$ This refers to the state's interventionist positive discrimination (or affirmative actions) in favour of Bumiputera. This is embodied in the NEP that aimed to restructure wealth in the country, particularly through creating Bumiputera business community and achieving $30 \%$ share of equity ownership for the Bumiputera.
} 
including depriving the MCA of their Finance, and Commerce and Industry portfolios which since independence were under the power of the MCA president. The prime minister resigned in 1970 and in January 1971 parliamentary government resumed and the new government launched the NEP.

The ethnic clash formed a critical juncture in the Bumiputera institution's development as the UMNO elites' ideological influence on political actions was significantly reduced and the younger Malay nationalists took effective control of the government. From this critical juncture, the range of plausible choices open to powerful actors, especially the young Malay nationalists, expanded substantially and their decisions concerning the Bumiputera institution affected future developments. The crisis manifested the ideological clash between the young nationalists within UMNO and the Malay elite leaders (Mohamad, 2008). In short, the incident had a significant political impact on the country: it helped reduce the influence of older UMNO leaders, who had favored the Chinese, and enabled the younger Malay leaders supporting the Malays' prominence.

In this critical juncture, the younger leaders took the opportunity to devise policies aimed at improving the Malays' economic condition and to present a pro-Malay NEP. From our historical institutional perspective, this structured a political struggle into a policy outcome within which the willful actors organized their interests and created a decisionmaking situation for a particular group of actors to exercise certain powers. The actors' willfulness developed the power position that emerged from this historically significant circumstance which we understand as a concrete temporal process.

\subsubsection{Development of NEP - the role of power}

A counterfactual analysis of the new economic policy's introduction shows that the NEP resulted from a clash of interests and power between the country's two major groups. This is because the NEP was drafted by two competing departments pushing different ideas to protect their group's interests: the Economic Planning Unit established in 1961 and headed by a Chinese official and staffed by several Chinese economists and which formulated the country's economic policy since independence represented the interests of the economically dominant non-Bumiputera, and the Department of National Unity set up on July 1, 1969 following the ethnic clash representing Bumiputera interests (Heng, 1997). ${ }^{16}$

The policy the Economic Planning Unit pursued was inherited from the colonial system. Its conservative approach emphasized a balanced budget, growth first and distribution later, more effective policy and strategy implementation, and maintaining political stability with minimum government involvement in economic affairs. It deemed the May 1969 riots an unfortunate event that should not affect economic policy formulation. The newly established Department of National Unity, however, viewed the riots as manifestation of a structural defect in the country's political economy which required measures to tackle economic imbalances between the ethnic groups, especially as these imbalances affected

16 The UMNO elites' pro-Chinese approach meant the Chinese controlled the country's important economic portfolios, including the Ministry of Finance, which appointed the Governor of Bank Negara (Malaysian Central Bank). 
ethnic integration, national unity, and social stability. They put forward a radical alternative in the NEP which sought to advance Bumiputera interests and specified targets for Bumiputera participation in the economy.

The Economic Policy Unit's proposals received support from the Finance Minister who was also president of the MCA and deemed a very respectable and powerful politician: "without his approval no policy could be adopted" (Faaland, Parkinson, \& Saniman, 1990, p. 30). Consequently, the Department of National Unity's proposals were accepted as the first draft of the NEP. The Economic Committee of the National Consultative Council was established by the government, comprising representatives from various groups to deliberate on the draft. However, the Council's deliberations were not publicized; rationalization of the ideas only occurred at the higher level. Given the sensitive nature of this issue, policy deliberations were kept out of the media to allow thorough discussion and a consensus that benefited all Malaysians (ibid).

The MCA had minimal input into the NEP. The ethnic clash weakened the Chinese at both social and political levels. However, the MCA president still managed to use his office of Minister of Finance to delay the policy's implementation (Heng, 1997). The NEP was only properly implemented after the MCA president resigned from his position in 1974, but the final policy was considered moderate for several reasons. First, ethnic leaders were focused on high-level co-operation which enabled compromise. Secondly, policy differences between the Department of National Unity and the Economic Policy Unit resulted in compromises in policy-making. Thirdly, the Chinese community had some electoral support (Geoffrey \& Stafford, 1997). The NEP thus encompassed an explicit commitment to the Bumiputera people. ${ }^{17}$ Following its establishment, the state made various efforts to achieve the policy's objectives. The following section discusses these efforts affecting Bumiputera representation on corporate boards of directors and their share of equity ownership.

\subsubsection{Impact on corporate governance}

In pursuit of Bumiputera interest the NEP set targets for equity ownership: 30:40:30 for Bumiputera, non-Bumiputera and foreign investors, respectively. In the NEP's early years, the government established and strengthened various mechanisms to benefit the Bumiputera and passed the Industrial Coordination Act of 1975. Through the various newly formed bodies $^{18}$ the government acquired equity ownership from foreign shareholders and started forming state-owned-enterprises. The government also introduced the Foreign Investment Committee in 1974 to achieve the NEP's objective of 30\% Bumiputera equity ownership. ${ }^{19}$

\footnotetext{
17 The NEP had two general aims: poverty eradication regardless of race and restructuring society to eliminate the identification of race with the economic function.

18 The bodies include the investment holding company, the "Perbadanan Nasional Berhad" (National Trading Corporation or PERNAS), established in 1969; establishing the "Yayasan Pelaburan Bumiputera" (Bumiputera Investment Foundation) and its investment company, "Permodalan Nasional Berhad" (National Equity Corporation or PNB) in 1978.

19 This led to the Guidelines on Acquisition of Assets, Mergers and Take-Overs being established in 1974 which regulated matters on foreign investment and imposed specific conditions on firms seeking a listing in Malaysia, including the 30\% Bumiputera equity participation requirement. The 1974 Guidelines were updated in 2004 and subsequently repealed in 2009 as the country entered a neoliberal era.
} 
In the early 1980s, in response to a slowing economy, the government liberalized its policy to promote growth and pursued a privatization policy for national development and to promote Bumiputera participation in the corporate sector. Although in 1990 the NEP officially ended, the policy of advancing Bumiputera interests continued. In the Sixth Malaysian Plan 1990-1995, the government announced the Bumiputera Commercial and Industrial Community $(\mathrm{BClC})$ to create competitive and resilient small-and-medium scale Bumiputera enterprises in strategic sectors and introduced the Bumiputera Joint-Venture Scheme to achieve the $30 \%$ equity target for Bumiputera. ${ }^{20}$

The government's efforts and economic expansion resulted in a steady increase in Bumiputera equity ownership during 1970 to 1985. Non-Bumiputera equity also increased while foreign ownership continued to decline (see Figure 2). In fact, in 1980 non-Bumiputera share ownership reached $40 \%$ with a significant increase in individual Bumiputera equity ownership and in holding of trust agencies. Bumiputera equity ownership was also affected through PERNAS which over time acquired shares owned by foreigners and held them in trust (Geoffrey \& Stafford, 1997). There was also growth of state-owned enterprises providing employment opportunities for the Bumiputera (Haggard \& Low, 2000).

Bumiputera representation on corporate boards of directors started to increase with the formation of the NEP although foreign directors dominated boards (see Figure 3a). In the early years of the Policy Malay directors were not involved in managing business but were 'functional directors' who performed extra-economic functions for the corporation and sometimes symbolically represented the Bumiputera (Lim, 1981). Their presence was politically significant for securing contracts, tenders, licenses, and concessions from the state. Prominent Malay politicians or former civil servants were needed on the boards because the government was a major client and there was an increase in government regulation of the private sector (Lim, 1985). In 1974 for example, compared with about 7\% Chinese, 50\% of Malay directors were politicians or civil servants (Lim, 1981). Also, more than $50 \%$ of Malay directors held a state-conferred title compared with only $15 \%$ of Chinese directors. ${ }^{21}$ In contrast to more than $70 \%$ of Chinese directors only $35 \%$ of Malay directors had a business background. Having influential directors on boards helped companies exert influence over the government in shaping economic policies (Lim, 1981). Additionally, Bumiputera representation on corporate boards helped them become familiar with business affairs, and mitigate their marginalization in employment (Mohamad, 1970).

The mid-1980s privatization policy also significantly influenced share ownership as Bumiputera ownership increased to $18.5 \%$ and non-Bumiputera reached $50 \%$, while foreign ownership fell to its lowest at $24 \%$. The privatization policy also marked the emergence of GLCs ${ }^{22}$, whose board members were mainly Malay, to further Bumiputera interests. In 1990,

\footnotetext{
20 The BCIC is a consortium of commercial banks to finance the establishment of joint-ventures between Bumiputera and non-Bumiputera entrepreneurs.

21 This refers to the title obtained through a knighthood conferred by Sultans or the state.

${ }^{22}$ GLCs are defined as companies that have a primary commercial objective and are under the control of a GovernmentLinked Investment Companies (GLICs). A GLIC has control over GLC when it is the majority shareholder or single largest shareholder and when it has the ability to exercise and influence major decisions such as appointment of board members and senior management, award of tenders and contracts and so on. GLICs are defined as Federal Government-
} 
Bumiputera share of equity ownership stood at $19.3 \%$ far below the $30 \%$ target and foreign ownership started to surge because, besides privatization, the liberalization strategy after 1985, when foreign ownership was at its lowest level, meant the government promoted inflows of foreign investment to boost export-oriented industrialization (Fukunaga, 2010). In contrast non-Bumiputera equity peaked in 1985 and then started to decline.

In terms of breakdown of Bumiputera equity ownership, Bumiputera individuals accounted for only slightly more than a third of total Bumiputera equity in 1980, but their ownership grew at a faster rate of $32 \%$ per annum. ${ }^{23}$ By 1985, Bumiputera individuals accounted for more than the share of trust agencies (EPU, 1986, p. 106). Between 1990 and 1995 , trust agencies' share of ownership reduced because of privatization and the sale of some trust agencies' holdings to Bumiputera individuals and GLCs. During this period, there was a focus on changing the control of corporates with Bumiputera individuals or groups "taking the corporate scene by storm": Bumiputera companies started taking over Chinese businesses and there was a growing trend of Bumiputera-Chinese business partnerships (Cheong, 1993, p. 363). ${ }^{24}$

Increased Bumiputera interest in public listed companies also increased the number of Malay directors and they started to dominate the boards of directors. The number of Bumiputera owner-directors in public listed companies also increased. Phase 2, therefore, shows that the Bumiputera institution altered the power structure within the country by strengthening the previously subordinate actors of young Malay nationalists at the expense of the previously dominant ones from UMNO and the MCA (Mahoney, 2000). The advantaged group of young Malays used their additional power to expand the Bumiputera institution further, primarily by establishing the NEP. This expansion increased the UMNO leaders' power and strengthened the institution thereby affecting Bumiputera equity ownership and representation on corporate boards of directors.

\subsection{Phase 3: The critical juncture reproducing Bumiputera}

While Phase 1 and Phase 2 show equity ownership and corporate board representations evolved through the Bumiputera institution, Phase 3 shows how this critical juncture affected the Bumiputera institution and thereby also directly affected governance reforms and structures as the country sought to respond to international concerns about governance in the region. The Asian crisis opened various contingencies regarding the Bumiputera institution's development and had implications for Bumiputera's stake in the economy, including their share of corporate equity ownership. Nevertheless, despite various pressures the Bumiputera institution persists, as the analysis below will show, demonstrating how power helped reproduce the Bumiputera institution following the critical juncture. Although

\footnotetext{
Linked Investment Companies that allocate some or all of their funds to GLC investments. Their board members and senior management report directly to the Government (PCG - Putrajaya Committee on GLC High Performance, 2015).

${ }^{23}$ Individuals include contributions made by private Bumiputera enterprises, the National Unit Trust Scheme, and the PNB.

${ }^{24}$ In 1993, 48 public companies were under the control of Bumiputera individuals and companies, and 26 companies were under the control of GLCs.
} 
the 30\% Bumiputera equity requirement developed in Phase 2 was removed during Phase 3, commitment to the Bumiputera institution remained. The Bumiputera institution was reproduced through support from an elite group of actors (i.e. UMNO). This echoes how "an institution can persist even when most individuals or groups prefer to change it, provided that an elite that benefits from the existing arrangement has sufficient strength to promote its reproduction" (Mahoney, 2000, p. 521).

This critical juncture brought governance to the fore and to the publication of the Malaysian Code on Corporate Governance (MCCG) in March 2000. Because of the global proliferation of neoliberal agenda and its impact on corporate governance practices (see Harvey, 2005; Morales, Gendron, \& Guénin-Paracini, 2014; Chiapello, 2017), the Code reinforced the country's acceptance of global best practices in governance. However, there is a paradox. As we see below, ethnicity is still implicated in board representation and corporate ownership structures due to Bumiputera influence. Although the Asian crisis resulted in the adoption of mechanisms to strengthen governance practices, it also prompted another critical juncture which threatened Bumiputera institution's path dependence and raised questions regarding the fairness of targets for corporate equity ownership and representation on boards of directors. Also, while the governance code signals adoption of neoliberal policies intended to attract international investment, the government's commitment to pursue Bumiputera interest remains powerful.

\subsubsection{Another critical juncture - The Asian crisis and the New Economic Model}

The 1997/98 Asian crisis raised international criticisms about political practices, economic structures and governance in the region (Corsetti, 1998). Malaysia was compelled to adopt immediate measures aimed at improving corporate governance. ${ }^{25}$ Also, as the country was becoming less competitive in attracting foreign investment, economic reform was deemed urgent and thus the government pursued neoliberal economic policies. As we see below, this was not uncommon in many non-western countries as neoliberalism has challenged almost all prevailing institutions and practices (Hopper, Lassou, \& Soobaroyen, 2017). Consequently, the Bumiputera policy was put on the back burner, threatening the Bumiputera institution's path dependence. In 2009, the new prime minister Abdullah Ahmad Badawi announced further liberalization efforts and removed the 30\% Bumiputera equity quota which had defined the country's political system for 37 years. ${ }^{26}$

Another important development occurred soon afterwards when, in March 2010, the government released the New Economic Model (NEM) developed by the National Economic Advisory Council whose panel included high-profile figures, both local and foreign, such as an

\footnotetext{
25 Malaysian corporate governance was argued to be better (at least on paper) than that of the other four worst-hit countries (Thailand, Philippines, Indonesia, and Korea), as the country initiated measures to strengthen and modernize its regulatory framework for the corporate sector and capital market well before the Asian crisis. The only major problem was deemed to be poor compliance and enforcement (Capulong, Edwards, Webb, \& Zhuang, 2000).

26 The Foreign Investment Committee Guidelines that covered the acquisition of equity shares, mergers, and takeovers was also repealed, and Foreign Investment Committee will no longer process any share transaction nor impose equity conditions guidelines. In short, the $30 \%$ Bumiputera equity condition the Foreign Investment Committee imposed was removed because it had failed to achieve its objectives.
} 
ex-minister, a prominent economist, academic and corporate advisors, and World Bank representatives. The NEM aimed to take Malaysia out of the middle-income trap and make it a high-income country. Significantly, it espoused 'inclusive growth' which represented a radical shift and meant affirmative actions would no longer focus solely on Bumiputera but rather seek to treat all ethnic groups falling in specified income threshold fairly and equally. In promoting 'inclusive growth', the NEM report (National Economic Advisory Council, 2009, p. 4) observes:

Policies and strategies we used to achieve the current state of development are now inadequate to take us to the next stage [. . . .] The government must confront these realities and make tough decisions. We urgently need a radical change in our approach to economic development which will be sustainable over the long term, will reach everyone in the country and will enable Malaysia to reach high-income status.

The NEM report noted that the practice of ethnic quotas, which was imposed extensively throughout the economy, yielded unhealthy and pervasive rent-seeking and patronage activities that overshadowed and irreparably harmed key affirmative action programs. It asserted: "All stakeholders are demanding that these practices be revamped and changed to make them more effective, equitable, and inclusive." (p. 92). The report caused uproar among some Malay rights groups for its lack of regard for the Bumiputera (The Star, 2010). Recognizing the adverse implications for Bumiputera's interests, Malay non-governmental organizations established a council called the Malay Consultative Council to oppose the document. Two groups of dominant actors were thus formed: the National Economic Advisory Council and its supporters favoring the removal of Bumiputera affirmative policy and the Malay Consultative Council who opposed it.

The counterfactual analysis, in the following section, shows how this Malay group was able to exert pressure on the government to recommit to the pursuit of Bumiputera interests. Given the economic situation the country was facing and that the NEM was drawn up by the Council, which included local and foreign economic experts, the Model should have prevailed. However, the Malay Consultative Council's resistance and its utilization of political power resulted in softening of the position taken. The following section discusses the Malay Consultative Council's and the Chinese reaction to the NEM document and the government's response to the struggles.

\subsubsection{Struggles against and in support of the NEM}

The Malay Consultative Council has been a noteworthy influence on government policy towards Bumiputera. Formed by 76 Malay non-governmental organizations in February 2010, and headed by an independent minister of parliament Ibrahim Ali, it sought to defend and protect Bumiputera rights and interests, especially to safeguard Malay rights contained in Article 153 of the Constitution. On May 29, 2010, it convened the Bumiputera Economic Congress to respond to the first part of the NEM document and pressured the government 
into reconsidering the intention to remove the Bumiputera policy. Following the congress, the Tenth Malaysian Plan 2011-2015 containing explicit measures to promote Bumiputera interests was released.

While the Malay Consultative Council strongly opposed the NEM, in contrast the Chinese community supported it. In August 2010, the MCA organized a similar congress, the Chinese Economic Congress, which pledged support for the Model and for the removal of Bumiputera's special position. In the resolutions adopted, it cites the impact of policies on corporate governance in Malaysia (MCA, 2010):

Resolution 3: In line with the promotion of good governance and greater transparency, the Congress urges the Government to practice an open tender system in government procurement to achieve a level playing field in the local business environment, and the gradual removal of $30 \%$ Bumiputera equity in all sectors of the economy.

Resolution 4: The Congress urges the Government to practice inclusive policies by liberalizing the GLCs to include more multi-ethnic Boards of Directors and workforce within the GLC eco-system, and to award contracts to the best qualified local companies in their tender, regardless of their equity composition.

These resolutions increased the pressure on the government and threatened Bumiputera interests. However, despite resistance from the National Economic Advisory Council and the MCA, the government's commitment towards the Bumiputera continued as the second part of NEM was amended to include measures relevant to the Bumiputera, including continuing specific programs for Bumiputera small and medium enterprises and retaining Bumiputera corporate equity ownership target of $30 \%$. Table 1 summarizes government efforts to further Bumiputera interests and increase wealth in general but more specifically to increase Malay ownership and representation on corporate boards.

\section{[Insert Table 1 about here]}

\subsubsection{Governance in post Asian crisis period}

The Asian financial crisis brought international criticisms regarding corporate failures and weak governance systems (Calomiris, 1998). In March 1998, the government announced plans for establishing the Malaysian Institute of Corporate Governance and the High-Level Finance Committee on Corporate Governance. This coordinated effort between the government and the private sector sought to establish a framework for corporate governance and set industry best practices. ${ }^{27}$ In March 1999 the Committee published its report covering three broad

\footnotetext{
27 The High Level Finance Committee is chaired by the Secretary General of Treasury (Ministry of Finance); members are Malaysian Securities Commission (SC), Financial Reporting Foundation, Malaysian Accounting Standards Board, Companies Commission of Malaysia, the then Bursa Malaysia, Malaysian Institute of Chartered Secretaries and
} 
areas: amending relevant laws; introducing mandatory training for directors; and developing the MCCG 2000.

Modelled on UK corporate governance, the Code marks a significant milestone in governance reform in Malaysia. It sets out principles and best practices on the structures and processes which companies may use to achieve an optimal governance framework. It contains guidelines on board composition, procedures for recruiting new directors, remuneration of directors, and the use of board committees. The Code also recommends that boards should include both executive directors and non-executive directors (including independent nonexecutives) so that no individual or small group can dominate board decision-making. Also, there should be a formal and transparent procedure for appointing new directors to the board. ${ }^{28}$

In 2007 the Code was revised to strengthen the roles and responsibilities of the board of directors, the audit committee, and the internal audit function. The revised Code details the audit committee's composition, frequency of meeting, and need to update its knowledge. All public listed companies must conduct their own internal audit. The Revised MCCG 2007 also spells out the eligibility criteria for appointing directors. In 2010 the International Corporate Governance Consultative Committee was formed to provide strategic direction, views, and advice to the Securities Commission in developing a new five-year blueprint that outlined an action plan to further raise the standards of governance in Malaysia. This led to the issuance of a Corporate Governance Blueprint in 2011 which outlines strategic initiatives for strengthening self and market discipline and emphasizes promoting and internalizing the culture of good governance.

The MCCG was thus further revised in 2012 to strengthen board structure and composition. It noted that directors must be effective stewards and guardians of the company, not just in setting strategic directions and overseeing business operations but also in ensuring company conduct complies with laws and ethical values. Directors are also expected to maintain an effective governance structure to ensure the appropriate management of risks and level of internal controls. The Code was revised again in 2017 to strengthen corporate culture anchored on accountability and transparency. It introduced the "Comprehend, Apply and Report (CARE)" approach which requires companies to "apply or explain an alternative" practice and marks a shift from the prevalent "comply or explain" approach. International Integrated Reporting Council welcomed the revised Code, especially the move to introduce integrated reporting in Malaysia. Figure 4 summarizes this development.

\section{[Insert Figure 4 about here]}

\footnotetext{
Administrator, Malaysian Central Bank, Association of Banks Malaysia, Association of Stock-broking Companies Malaysia, and Federation of Public Listed Companies.

${ }^{28}$ Part 2 of the MCCG 2000 sets out best practices for companies, including separating the role of the board chairman and Chief Executive Officer (CEO), and ensuring Independent Non-Executive Directors form at least one-third of the board. Where the roles of the board chairman and CEO are combined, the board should have a strong independent element. A decision to combine the roles of Chairman and CEO should be publicly explained.
} 
Notwithstanding the adoption of corporate governance codes, Bumiputera institution continues to affect governance practices. As discussed under Phase 2, Bumiputera institution led to the emergence of GLC. The state's involvement in the economy through GLCs has, in turn, shaped governance practices: in GLCs the Malaysian Government has a direct controlling stake and thus affects major decisions including the appointment of board members and senior management. As GLCs and GLICs are mechanisms for pursuing Bumiputera interests, their boards and CEO positions are dominated by Bumiputera. The GLC Transformation Program states in its Green Book ${ }^{29}$ :

In expanding the pool of potential directors, GLC Boards should look to those individuals who understand, and are sensitive to, the national development objectives of the GLC Transformation Program, the National Mission and Vision 2020. (PCG, 2006, p.11).

Unlike non-GLCs, which mainly pursue economic interests, GLCs have social obligations that require boards to balance and manage sometimes opposing interests of various stakeholders. Therefore, GLC decisions are not always predicated on economic rationales but serve other purpose and interests, including fulfilling social obligations towards Bumiputera and the public in general:

"GLCS often have to carry social obligations such as providing universal access to basic services or develop a local and Bumiputera supplier base, even though it is uneconomical, or less than economical, for the GLC to do so. The Board should be engaged on the economic impact of these social obligations - including the benefits that the GLC derives (such as monopoly rights) and the actual costs associated with delivering the service." (PCG, 2006, p. 22).

For non-GLCs, Bumiputera policy means that appointing Malay directors is sometimes a legal imperative. For instance, to apply for Bumiputera status ${ }^{30}$, operate in the oil and gas industry, or to obtain a licence from Malaysia's national petroleum company - PETRONAS ${ }^{31}$, companies must ensure that Bumiputera always have a majority share of equity ownership, representation on board of directors and other key positions. Apart from this, there is no specific requirement to enforce Bumiputera representation on corporate boards of directors.

\footnotetext{
29 The initiatives for GLC transformation are identified and organized into 'Execution Books'. Green Book is one of these; it contains the initiatives for enhancing board effectiveness.

30 Bumiputera status is needed to obtain certain government projects or operate in the industries reserved for Bumiputera.

${ }^{31}$ Petroliam Nasional Berhad (PETRONAS) is Malaysia's fully integrated oil and gas multinational corporation. An entity wishes to provide goods or services to the upstream sector in the oil and gas industry in Malaysia (which involves exploration, development and production of oil and gas) must have a valid licence issued by PETRONAS. Issuance of PETRONAS Licence is based on the Petroleum Development Act and Petroleum Regulations 1974 (PETRONAS, 2014).
} 


\subsubsection{Impact on Bumiputera equity ownership and board representation}

Figure 2 shows that immediately following the Asian economic crisis, equity ownership of both the Bumiputera and non-Bumiputera declined. From 2000, the non-Bumiputera ownership steadily declined while the Bumiputera share remained constant at $18.9 \%$ until 2004 before rising slightly in 2008. In 2010, Bumiputera equity ownership stood at $23.09 \%$ (worth RM167.7 billion) compared with 21\% (worth RM127.08 billion) in 2008 (Bernama, 2012). A year later, in 2011, it increased slightly to $23.5 \%$ (worth RM211.5 billion) - the highest level of Bumiputera equity recorded since the NEP was established, while non-Bumiputera ownership dropped further to $34.6 \%$ (worth RM311.6 billion) (Jalil, 2015). Also, Figures 3b and $3 \mathrm{c}$ show Bumiputera continue to have a significant presence on corporate boards, at least in the top 100 companies listed on Bursa Malaysia.

More significant is the strong position and performance of GLCs. In 2005, the government launched the GLC Transformation Program 2005-2015. Its 2015 'graduation' report (PCG, 2015) shows the market capitalization of the top 20 GLCs grew almost three times to RM386 billion from May 14, 2004 to July 28, 2015 (the last day of the Program), reaching an all-time high of RM431 billion on April 7, 2015. Total shareholder returns grew $11.1 \%$ per annum over the same period. They also made RM153.9 billion worth of domestic investments during 2004-2014 and in 2014 had 225,050 Malay employees. In addition, they contributed RM108.3 billion in dividends and RM63.5 billion in taxes during 2001-2014. While GLCs are promoting growth with inclusivity, 79\% of the workforce in the top 20 GLCs in 2014 was Bumiputera. The government also developed Bumiputera Empowerment Agenda to increase commitment of GLCs and GLICs to the Bumiputera agenda (ibid).

Our analysis focused on critical junctures reveals that Bumiputera has been gradually and subtly developed, institutionalized, and reproduced despite crises, struggles, and counterfactuals. Phase 3 shows the institutional significance of Bumiputera in terms of its path-dependence roots. Indeed, these path-dependence roots were gradually and subtly institutionalized in relation to counterfactuals and contingences. Critical junctures thus represent this entire process, which is temporal, fragile, and politically and ideologically discursive. We find that Bumiputera is a reproductive phenomenon and corporate governance is a representation and manifestation of how corporate ownership and board structures are institutionally reproduced rather than a mere response to globalized and isomorphic governance rationales.

\section{DISCUSSION AND CONCLUSION}

\subsection{Politics, critical junctures, and governance}

This paper traced the trajectory of Bumiputera affirmative policy that shaped board representation and ownership structures in Malaysia using historical institutionalism as a lens. In this regard, we explored three interrelated questions: (1) what critical junctures shaped postcolonial ethnic-politics and in turn affected equity ownership representation on corporate boards of directors? (2) how did these critical junctures become path-dependent 
in reproducing ownership and board structures? (3) what counterfactuals and contingencies were present in relation to these changes?

We examined the role of a series of critical junctures, i.e. (i) the rejection of British administrators' proposals for a Union policy; (ii) independence in 1957; (iii) the ethnic clash of 1969; (iv) the 1997/1998 Asian economic crisis and its implication for post-crisis policies; and (v) the 2010 NEM which affected Bumiputera interest and governance reform, in particular, ownership and board structures. These events also manifested as critical junctures with enough contingencies and counterfactuals reinforcing Bumiputera as a significant path dependent institution. Bumiputera also manifested as a political agenda that challenged colonial rule and values which undermined native Malays' place in the economy and in society. The Malays perceived they had an 'unfair' social status, especially because due to the colonial polity, non-Malays dominated corporate boards and equity ownership. The series of critical junctures that gradually and subtly helped establish the Bumiputera as an alternative affirmative policy challenged the colonial polity, although power and politics played a crucial role in the transformation. This institutional change questioned the 'taken-for-granted' version of colonial polity and ushered in governance reform affecting corporate ownership and representation on boards of directors in Malaysia. This insight is an important contribution to embryonic, critical research on governance especially in emerging countries (see Uddin \& Choudhury, 2008; Bédard \& Gendron, 2010; Yonekura et al., 2012; Siddiqui \& Uddin, 2016; Hopper et al., 2017).

\subsection{Ethnicity as a vehicle for temporal processes in governance}

An important question scholars in critical junctures have addressed concerns the 'changepermitting' character in historical processes of gradual and subtle transformation. Our historical analysis of corporate governance reform in Malaysia suggests that ethnicity allowed willful actors to organize themselves and argue for a change in colonial polity that undermined native Malays and their Sultan-based governing traditions. The willful actors had an ideological basis to act on and convince others of their political project. It became a profoundly sustainable political project because actors were ideologically convinced and the underlying ideology was strategically mobilized. The basis is the ethnic element - the changepermitting character - that characterizes an endogenous force for gradual transformation rather than an exogenous force prompting dramatic change (Mahoney \& Thelen, 2010).

That said, in the reform of corporate governance in Malaysia, ethnicity acted as an endogenous force as opposed to an exogenous shift that the colonial rulers imposed on the economy and society. Our analysis reveals that grievances, which were salient as Malays were socially, politically, and economically disadvantaged, stimulated a 'change-permitting' property and developed a path-dependent process that affected ownership and board structures. This was possible because the grievances were ideologically rooted in ethnicity and the resultant repercussions created a discursive space for governance reform. Such a possibility is not new in historical institutional analysis. When exploring how institutional change can occur, some scholars have examined how actors affect power balances by 
engaging in multiple institutions (see Knight, 1992; Thelen, 1999). In our case, political and economic institutions shaped Bumiputera engagement in ethnic and cultural institutions. The Malays' grievances played a socio-political role in organizing this multiple engagement, hence the influence of critical junctures.

These contextual ramifications also show how power mechanisms work. Before independence, Chinese-Malays were gradually acquiring economic power while creating a form of competition for postcolonial economic prosperity. Our analysis suggests that critical junctures are inherently competitive in that one group of actors become powerful by mobilizing their institutional preferences, but this involves arguments and debates with competing groups of actors. This competition was historically significant and affected the series of critical junctures (discussed in Section 4). The Chinese were economically privileged while Malays were under-privileged and had less economic and political power. Consequently, willful actors (i.e. Malays) became much more cautious and competition between the two ethnic groups became institutionalized. As Schickler (2001) and Palier (2005) observed, institutions are fraught with tensions because they are confronted with resource considerations and distributional consequences. Compromises are thus difficult, but ethnicity was a powerful guiding rule for dominant actors facing ambiguities (Moe, 2005). Hence, for critical junctures to challenge prevailing institutions and to offer alternatives, conflicts and contradictions are important institutional conditions.

Above all, the Malays desired to become dominant and powerful. Although desire is a psychological property that can organize an institutional preference, it is also a defining principle for forming the subjectivity that leads to an endogenous force against exogenous forces (Slater, 2010). This desire served as a 'change-permitting' property in all the critical junctures we analyzed in Section 4. As the analysis suggests, such a desire has been a defining principle for all temporal processes of critical junctures and affected governance reforms considerably by giving the Bumiputera power in the form of a larger share of corporate equity ownership and representation on corporate boards of directors. Hence, ethnic politics has been an inevitable, endogenous force affecting governance reforms in Malaysia (c.f. Davie, 2005; Wickramasinghe \& Hopper, 2005; Efferin \& Hopper, 2007; Kim, 2008).

\subsection{Final remarks}

To conclude, this paper has explored a gradual and subtle institutional change in how governance structures were defined, maintained, and institutionalized in Malaysia. A series of critical junctures allowed us to unpack this trajectory of development. Our analysis shows that corporate governance practices in postcolonial settings such as Malaysia cannot simply be analyzed via historical institutions' broader structural categories. Instead, power and related subjective mechanisms, which enabled willful actors to mobilize, are important in understanding why particular governance structures and practices materialize, are sustained, and debated. Drawing on historical institutionalism and critical junctures, we contribute to the accounting literature on governance. As discussed earlier, mainstream research places emphasis on testing the statistical significance of relationships between governance 
attributes and indicators of reporting and auditing quality. Complementing such research, our analysis highlights willful actors' roles in mobilizing their ethnic and political positions to affect reforms and governance structures. In examining how governance attributes, such as ownership and board structures, are debated and institutionalized, we find they are not merely variables in a positivistic sense but also mechanisms through which we can understand how ethnicity contributes to gradual and subtle transformations of institutions. Our analysis reveals more about the evolution of governance. While positivist research often presumes that such codes are responses to secure shareholder confidence in capital markets, our analysis shows de-coupling shareholder perspectives from actual practices can happen according to the specific power issue at play (c.f. Tremblay \& Gendron, 2011). We do not deny the influence of capital markets but deem an exclusive focus on market explanations incomplete and providing only a partial understanding of governance reforms and the emergence of governance structures.

Although our paper provides a contextual historical understanding of governance reform, in particular of corporate ownership and board representation, it lacks detailed accounts of actors' views to triangulate (Modell, 2009) the textual materials into a meaningful case study. Nevertheless, our paper does offer a point of departure for such case-based research which can explore issues about how actors interact in diverse historic-institutional contexts and challenge prevailing governance ideas. Moreover, current variations of institutional theory, including institutional logics, institutional work, and institutional rhetoric, can be triangulated with critical junctures to address incremental change in governance practices to explore governance reforms and practices, including the promotion and use of affirmative policies and quotas. Such theoretical ideas may capture the emerging calls for critical accounting on issues of accounting, race and ethnicity which reflect the impacts of neoliberalism, financialization and globalization (Lehman, Annisette, \& Agyemang, 2016; Annisette \& Prasad, 2017; Chiapello, 2017; Hopper et al, 2017). More detailed, case-based analyses can be a meaningful epistemological strategy for future research to "better narrate, unveil and undo the contemporary enactment" (Annisette \& Prasad, 2017, p. 16) of ideological ramifications of temporal processes and the roles of willful actors in the construction of accounting and governance. 


\section{REFERENCES:}

Ahrens, T., \& Chapman, C. S. (2006). Doing qualitative field research in management accounting: Positioning data to contribute to theory. Accounting, Organizations and Society, 31(8), 819841.

Al-Shaer, H., \& Zaman, M. (2016). Board gender diversity and sustainability reporting quality. Journal of Contemporary Accounting \& Economics, 12(3), 210-222.

Annisette, M., \& Prasad, A. (2017). Critical accounting research in hyper-racial times. Critical Perspectives on Accounting, 43, 5-19.

Bédard, J., \& Gendron, Y. (2010). Strengthening the financial reporting system: Can audit committees deliver?. International Journal of Auditing, 14(2), 174-210.

Bernama. (2012, April 23). Bumiputera equity ownership rose to 23.09pc in 2010, The New Strait Times. Retrieved from http://www.nst.com.my/top-news/bumiputera-equity-ownershiprose-to-23-09pc-in-2010-1.76890?localLinksEnabled=false\#

Brennan, N.M., \& Solomon, J. (2008). Corporate governance, accountability and mechanisms of accountability: an overview. Accounting, Auditing \& Accountability Journal, 21(7), 885-906.

Bushman, R. M., Piotroski, J. D., \& Smith, A. J. (2004). What determines corporate transparency? Journal of Accounting Research, 42(2), 207-252.

Calomiris, C. W. (1998). Blueprints for a new global financial architecture. Retrieved from http://www.house.gov/jec/imf/blueprnt.htm

Campbell, J. L. (2004). Institutional change and globalization. New Jersey, Oxfordshire: Princeton University Press.

Capoccia, G., \& Kelemen, R. D. (2007). The Study of Critical Junctures: Theory, Narrative, and Counterfactuals in Historical Institutionalism. World Politics, 59(3), 341-369.

Capulong, M. V., Edwards, D., Webb, D., \& Zhuang, J. (2000). Corporate Governance and Finance in East Asia: A Study of Indonesia, Republic of Korea, Malaysia, Philippines, and Thailand: Volume One (A Consolidated Report): Asian Development Bank.

Cheong, S. (1993). Bumiputera Companies in the KLSE. 2nd ed. Petaling Jaya, Malaysia: Corporate Research Services.

Chiapello, E. (2017). Critical accounting research and neoliberalism. Critical Perspectives on Accounting, 43, 47-64.

Clegg, S. (2006). The bounds of rationality: Power/history/imagination. Critical Perspectives on Accounting, 17(7), 847-863.

Collier, R. B., \& Collier, D. (1991). Shaping the political arena: Critical junctures, the labor movement, and regime dynamics in Latin America, (pp. 27-39). Princeton NJ: Princeton University Press.

Corsetti, G. (1998). Interpreting the Asian financial crisis: Open issues in theory and policy. Asian Development Review, 16(2), 1-45.

Coyle B. (2007). Corporate governance. 5th ed. London: Institute of Chartered Secretaries and Administrators.

Davie, S. S. (2005). The politics of accounting, race and ethnicity: a story of a Chiefly-based preferencing. Critical Perspectives on Accounting, 16(5), 551-577.

Davis-Friday, P. Y., Eng, L. L., \& Liu, C.S. (2006). The effects of the Asian crisis, corporate governance and accounting system on the valuation of book value and earnings. The International Journal of Accounting, 41(1), 22-40. 
Efferin, S., \& Hopper, T. (2007). Management control, culture and ethnicity in a Chinese Indonesian company. Accounting, Organizations and Society, 32(3), 223-262.

EPU - Economic Planning Unit. (1971). Second Malaysia Plan, 1971-1975. Retrieved from http://www.epu.gov.my/en/rmk/second-malaysia-plan-1971-1975

EPU - Economic Planning Unit. (1976). Third Malaysia Plan, 1976-1980. Retrieved from http://www.epu.gov.my/en/rmk/third-malaysia-plan-1976-1980

EPU - Economic Planning Unit. (1981). Fourth Malaysia Plan, 1981-1985. Retrieved from http://www.epu.gov.my/en/rmk/fourth-malaysia-plan-1981-1985

EPU - Economic Planning Unit. (1986). Fifth Malaysia Plan, 1986-1990. Retrieved from http://www.epu.gov.my/en/rmk/fifth-malaysia-plan-1986-1990

EPU - Economic Planning Unit. (1990). Sixth Malaysia Plan, 1990-1995. Retrieved from http://www.epu.gov.my/en/rmk/sixth-malaysia-plan-1990-1995

EPU - Economic Planning Unit. (1996). Seventh Malaysia Plan, 1996-2000. Retrieved from http://www.epu.gov.my/en/rmk/seventh-malaysia-plan-1996-2000

EPU - Economic Planning Unit. (2006). Ninth Malaysia Plan, 2006-2010. Retrieved from http://www.epu.gov.my/en/rmk/ninth-malaysia-plan-2006-2010

EPU - Economic Planning Unit. (2011). Tenth Malaysia Plan, 2011-2015. Retrieved from http://www.epu.gov.my/en/rmk/tenth-malaysia-plan-2011-2015

EPU - Economic Planning Unit. (2015). Eleventh Malaysia Plan, 2016-2020. Retrieved from http://www.epu.gov.my/en/rmk/eleventh-malaysia-plan-2016-2020

Ertman, T. (1997). Birth of the Leviathan: Building states and regimes in medieval and early modern Europe. Cambridge University Press.

Faaland, J., Parkinson, J. R., \& Saniman, R. (1990). Growth and inequality: Malaysia's New Economic Policy: C Hurst \& Co Publishers Ltd.

Fairclough, N. (2003). Analysing discourse: Textual analysis for social research. Psychology Press.

Flyvbjerg, B. (2001). Making social science matter: Why social inquiry fails and how it can succeed again. Cambridge university press.

Fukunaga, Y. (2010). Najib embarks on Bumiputra policy reform: Is real power possible in postMahathir Malaysia? Economic Review, 5, 1-9.

Fung, S. Y., Gul, F. A., \& Radhakrishnan, S. (2015). Corporate political connections and the 2008 Malaysian election. Accounting, Organizations and Society, 43, 67-86.

Funston, J. (1980). Malay Politics in Malaysia A Study of the United Malays National Organisation and Party Islam. Kuala Lumpur ; Singapore; Hong Kong: Heinemann Educational Books (Asia).

Gendron, Y., \& Bédard, J. (2006). On the constitution of audit committee effectiveness. Accounting, Organizations and Society, 31(3), 211-239.

Geoffrey, D., \& Stafford, S. D. (1997). Malaysia's New Economic Policy and the global economy: The evolution of ethnic accommodation. The Pacific Review, 10(4), 556 - 580.

Gul, F. A., Zhou, G. S., \& Zhu, X. K. (2013). Investor protection, firm informational problems, Big N auditors, and cost of debt around the world. Auditing: A Journal of Practice \& Theory, 32(3), 1-30.

Haggard, S., \& Low, L. (2000). The political economy of Malaysian capital controls; Retrieved from http://wwwirps.ucsd.edu/faculty/shaggard/Malaysia.13a.doc.html

Hall, P. A., \& Taylor, R. C. R. (1996). Political Science and the Three New Institutionalisms. Political Studies, 44(5), 936-957. 
Haniffa, R., \& Hudaib, M. (2006). Corporate governance structure and performance of Malaysian listed companies. Journal of Business Finance \& Accounting, 33(7-8), 1034-1062.

Hansen, W. L., Johnson, R. J., \& Unah, I. (1995). Specialized courts, bureaucratic agencies, and the politics of US trade policy. American Journal of Political Science, 529-557.

Hart, M. (1994). Coercion or Cooperation: Social Policy and Future Trade Negotiations. Can.-USLJ, 20, 351.

Harvey, D. (2005). Neo- liberalism: A brief history. Oxford: Oxford University Press.

Hay, C., \& Wincott, D. (1998). Structure, Agency and Historical Institutionalism. Political Studies, 46(5), 951-957. doi: 10.1111/1467-9248.00177

Heng, P. K. (1997). The New Economic Policy and the Chinese community in Peninsular Malaysia. The Developing Economies, 35(3), 262-292.

Hill, C.W.L., \& Jones, T.M. (1992). Stakeholder-Agency Theory. Journal of Management Studies, 29(2), 131-154.

Hopper, T., Lassou, P., \& Soobaroyen, T. (2017). Globalisation, accounting and developing countries. Critical Perspectives on Accounting, 43, 125-148.

Horii, K. (1991). Disintegration of the colonial economic legacies and social restructuring in Malaysia. The Developing Economies, 29(4), 281-313.

Huse, M. (2005). Accountability and creating accountability: A framework for exploring behavioural perspectives of corporate governance. British Journal of Management, 16, S65-S79.

Jalil, H. (2015, November 24). Increase in equity ownership of Bumiputera and Indians, The Sun Daily. Retrieved from http://www.thesundaily.my/news/1619531

Jesudason, J. V. (1989). Ethnicity and the economy: The state, Chinese Business, and multinationals in Malaysia: Oxford University Press.

Katznelson, I. (2003). Periodization and preferences: Reflections on purposive action in comparative historical social science. In J. Mahoney \& D. Rueschemeyer (Eds.), Comparative historical analysis in the social sciences (pp. 270-304). Cambridge: Cambridge University Press.

Kim, S. N. (2008). Whose voice is it anyway? Rethinking the oral history method in accounting research on race, ethnicity and gender. Critical Perspectives on Accounting, 19(8), 1346-1369.

Knight, J. (1992). Institutions and social conflict. Cambridge, New York, Oakleigh: Cambridge University Press.

Khoo, B. T. (2005). Ethnic structure, inequality and governance in the public sector: Malaysian experiences. Democracy, Governance and Human Rights, United Nations Research Institute for Social Development (UNRISD).

Khoo, S. M. (1987). Documenting papers on Bumiputra participation in the Malaysian economy. Library Review, Summer, 110-121.

Larcker, D. F., Richardson, S. A., \& Tuna, I. (2007). Corporate governance, accounting outcomes, and organizational performance. The Accounting Review, 82(4), 963-1008.

Lehman, C., Annisette, M., \& Agyemang, G. (2016). Immigration and neoliberalism: three cases and counter accounts. Accounting, Auditing \& Accountability Journal, 29(1), 43-79.

Leitch, S., \& Palmer, I. (2010). Analysing texts in context: Current practices and new protocols for critical discourse analysis in organization studies. Journal of Management Studies, 47(6), 1194-1212.

Lieberman, E. S. (2001). Causal inference in historical institutional analysis: A specification of periodization strategies. Comparative Political Studies, 34(9), 1011-1035. 
Lim, M. H. (1981). Ownership and control of the one hundred largest corporations in Malaysia. Kuala Lumpur, Oxford, New York, Melbourne: Oxford University Press.

Lim, M. H. (1985). Affirmative action, ethnicity and integration: The case of Malaysia. Ethnic and Racial Studies, 8(2), 250-276.

Lindenberg, M. (1973). Foreign and domestic investment in the pioneer industry program, Malaysia 1965-1970, political, economic, and social impacts. PhD Dissertation, University of Southern California.

Mahidin, M.U. (2017). Current population estimates, Malaysia, 2016-2017. Department of Statistics

Malaysia. Retrieved from
https://www.dosm.gov.my/v1/index.php?r=column/pdfPrev\&id=a1d1UTFZazd5ajJiRWFHND duOXFFQT09

Mahoney, J., \& Thelen, K. (2010). Explaining institutional change: ambiguity, agency, and power: Cambridge University Press.

Mahoney, J. (2000). Path dependence in historical sociology. Theory and Society, 29(4), 507-548.

Mat Zain, M., Zaman, M., \& Mohamed, Z. (2015). The effect of internal audit function quality and internal audit contribution to external audit on audit fees. International Journal of Auditing, 19(3), 134-147.

MCA - Malaysian Chinese Association. (2010). Chinese Economic Congress on New Economic Model. Retrieved from www.mca.org.my

Modell, S. (2009). In defence of triangulation: a critical realist approach to mixed methods research in management accounting. Management Accounting Research, 20 (3), 208-221.

Moe, T. M. (2005). Power and political institutions. Perspectives on politics, 3 (02), 215-233.

Mohamad, M. [Mahathir]. (1970). The Malay Dilemma. Kuala Lumpur, Singapore, Hong Kong: Federal Publications.

Mohamad, M. [Maznah]. (2008). Malay/Malaysian/Islamic: four genres of political writings and the postcoloniality of autochthonous texts. Postcolonial Studies, 11(3), 293 - 313.

Mollah, S. \& Zaman, M. (2015). Shari'ah supervision, corporate governance and performance: Conventional versus Islamic banks. Journal of Banking \& Finance, 58: 418-435

Morales, J., Gendron, Y., \& Guénin-Paracini, H. (2014). State privatization and the unrelenting expansion of neoliberalism: The case of the Greek financial crisis. Critical Perspectives on Accounting, 25(6), 423-445.

National Economic Advisory Council. (2009). New Economic Model for Malaysia - Part 1. Putrajaya, Malaysia: Percetakan Nasional Malaysia Berhad.

O'Connell, V. (2007). Reflections on stewardship reporting. Accounting Horizons, 21 (2), 215-27.

Palier, B. (2005). Ambiguous agreement, cumulative change: French social policy in the 1990s. In Beyond continuity: Institutional change in advanced political economies. Ed. Wolfgang Streeck \& Kathleen Thelen.127-144. Oxford University Press.

Parker, L. D. (2007). Financial and external reporting research: the broadening corporate governance challenge. Accounting and Business Research, 37 (1), 39-54.

PCG - Putrajaya Committee on GLC High Performance. (2006). The Green Book - Enhancing board effectiveness. Kuala Lumpur, Malaysia. Retrieved from www. pcg.gov.my

PCG - Putrajaya Committee on GLC High Performance. (2015). GLC Transformation Programme graduation report. Kuala Lumpur, Malaysia.

Perusek, G. (2002). Shifting terrain: styles of liberalism, periodization, and levels of analysis. International Journal of Politics, Culture, and Society,15 (3), 405-426. 
PETRONAS. (2014). General guidelines: Application for PETRONAS licence and registration. Kuala Lumpur, Malaysia. Retrieved from www.petronas.com.my

Reid, A. (1969). The Kuala Lumpur riots and the Malaysian political system. Australian Journal of International Affairs, 23(3), 258-278.

Richardson, A. J. (2008). Strategies in the development of accounting history as an academic discipline. Accounting History, 13(3), 247-280.

Salleh, Z., \& Stewart, J. (2012). The role of the audit committee in resolving auditor-client disagreements: a Malaysian study. Accounting, Auditing \& Accountability Journal, 25(8), 13401372.

Schickler, E. (2001). Disjointed pluralism: Institutional innovation and the development of the US Congress. Princeton University Press.

Siddiqui, J., \& Uddin, S. (2016). Human rights disasters, corporate accountability and the state: Lessons learned from Rana Plaza. Accounting, Auditing \& Accountability Journal, 29(4), 679-704.

Sikka, P., Puxty, A., Willmott, H., \& Cooper, C. (1998). The impossibility of eliminating the expectations gap: Some theory and evidence. Critical Perspectives on Accounting, 9(3), 299-330.

Skocpol, T. (1992). State formation and social policy in the United States. The American Behavioral Scientist, 35(4), 559.

Slater, D. (2010). Ordering power: Contentious politics and authoritarian leviathans in Southeast Asia. Cambridge University Press.

Sloan, R. G. (2001). Financial accounting and corporate governance: a discussion. Journal of Accounting and Economics, 32(1), 335-347.

Soifer, H. D. (2012). The causal logic of critical junctures. Comparative Political Studies, 45(12), 15721597.

Solomon J. (2007). Corporate governance and accountability. 2nd ed. New York, NY: John Wiley \& Sons.

Sopiee, M. N. (2005). From Malayan Union to Singapore Separation: Political Unification in the Malaysia Region 1945-1965 (2nd ed.). Kuala Lumpur, Malaysia: University of Malaya Press.

Tee, C. M., Gul, F. A., Foo, Y. B., \& Teh, C. G. (2017). Institutional Monitoring, Political connections and audit fees: Evidence from Malaysian firms. International Journal of Auditing, 21(2), 164-176.

Thelen, K. (2004). How institutions evolve: The political economy of skills in Germany, Britain, the United States, and Japan. Cambridge University Press.

Thelen, K. (1999). Historical institutionalism in comparative politics Annual Review of Political Science, 2(1), 369-404.

Thelen, K., \& Steinmo, S. (1992). Historical institutionalism in comparative politics. In S. Steinmo, K. Thelen \& F. Longstreth (Eds.), Structuring politics: Historical institutionalism in comparative analysis (pp. 1-32). Cambridge, Melbourne: Cambridge University Press.

The Economist. (2017, February 3). How powerful are Malaysia's sultans?, The Economist. Retrieved from https://www.economist.com/blogs/economist-explains/2017/02/economist-explains-1

The Star. (2010, April 2). Perkasa: NEM lacks Malay agenda, The Star. Retrieved from http://thestar.com.my/news/story.asp?file=/2010/4/2/nation/5984817\&sec=nation

Thomas, T. (2007). The social contract: Malaysia's constitutional covenant. In 14th Malaysian Law Conference. Kuala Lumpur.

Tremblay, M. S., \& Gendron, Y. (2011). Governance prescriptions under trial: On the interplay between the logics of resistance and compliance in audit committees. Critical Perspectives on Accounting, 22(3), 259-272. 
Turley, S., \& Zaman, M. (2004). The corporate governance effects of audit committees. Journal of Management and Governance, 8(3), 305-332.

Turley, S., \& Zaman, M. (2007). Audit committee effectiveness: A case study of informal processes and behavioural effects. Accounting, Auditing \& Accountability Journal, 20(5): 765-788

Uddin, S., \& Choudhury, J. (2008). Rationality, traditionalism and the state of corporate governance mechanisms: Illustrations from a less-developed country. Accounting, Auditing \& Accountability Journal, 21(7), 1026-1051.

Weber, M. (1978), Economy and Society: An Outline of Interpretive Sociology, in Roth, G. and Wittich, C. (Eds.), University of California Press, Berkeley.

Wheeler, D., \& Sillanpää, M. (1997). The stakeholder corporation: A blueprint for maximizing stakeholder value. Pitman.

White, N. J. (2004a). British Business in Post-colonial Malaysia, 1957-70: Neo-colonialism Or Disengagement?. Routledge.

White, N. J. (2004b). The beginnings of crony capitalism: business, politics and economic development in Malaysia, c. 1955-70. Modern Asian Studies, 38(02), 389-417.

Wickramasinghe, D., \& Hopper, T. (2005). A cultural political economy of management accounting controls: a case study of a textile Mill in a traditional Sinhalese village. Critical Perspectives on Accounting, 16(4), 473-503.

Wickramasinghe, D., \& Alawattage, C. (2007). Management accounting change: approaches and perspectives: Routledge.

Yonekura, A., Gallhofer, S., \& Haslam, J. (2012). Accounting disclosure, corporate governance and the battle for markets: The case of trade negotiations between Japan and the U.S. Critical Perspectives on Accounting, 23(4-5), 312-331.

Yong, H. H. (2004). 5 Men \& 5 Ideas: Building National Identity. Kuala Lumpur, Malaysia: Pelanduk Publications (M) Sdn Bhd.

Zaman, M., Hudaib, M., \& Haniffa, R. (2011). Corporate governance quality, audit fees and non-audit services fees. Journal of Business Finance \& Accounting, 38(1-2), 165-197. 
Figures and Tables

Independence

Independence
First Bumiputera Economic
Congress
Second Bumiputera
Economic Congress
May 13 Riots
New Economic Policy
launched

Emergence commitment to policy reversal

Privatization Policy launched

National Development Policy 1991-2000 launched

The Asian Economic Crisis

National Vision Policy 20012010 launched

\section{Liberalization Policy} announced

 intervention \\ - Share ownership dominated by foreigners and Chinese \\ - No presence of Malay on board of directors \\ - Interlocking ownership and interlocking directorship;} concentrated in small hands of Chinese.

$$
\text { 官 }
$$

- Requirement to have $10 \%$ Malay equity in pioneer companies

- Presence of Malay on board of directors despite minimal equity ownership

- Establishment of FIC to set up capital requirements for Bumiputera

- Bumiputera to reach 30\% equity by 1990

- Growth of SOEs

- The presence of Malay directors on Chinese board - Growth of state-owned enterprises
$\mapsto \quad$ - By 1979 presence of interlocking directorship in Malay

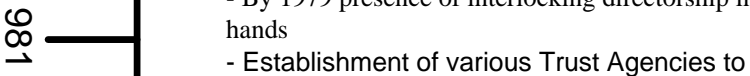 increase Bumiputera share ownership

$\infty$

- Emergence of GLCs significantly controlled by Bumiputera

- Presence of government control in GLCs

- Special Share hold by Ministry of Finance in certain

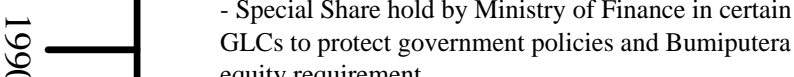
equity requirement

- Private Bumiputera shareholders own more equity than Trust Agencies

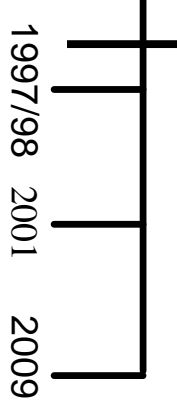

- The High Level Finance Committee on Corporate Governance, dominated by Malays, approved the introduction of Malaysian Code on Corporate Governance 2000

- FIC ended and hence removal of 30\% Bumiputera equity requirement

- SC's requirement for $25 \%$ spread maintained with $50 \%$ to be allocated to Bumiputera

- The presence of Malay directors on Chinese board is still significant even though failed to maintain substantive representation in equity ownership

Figure 1: Bumiputera - Critical Junctures, Policy Developments, and CG Impact 


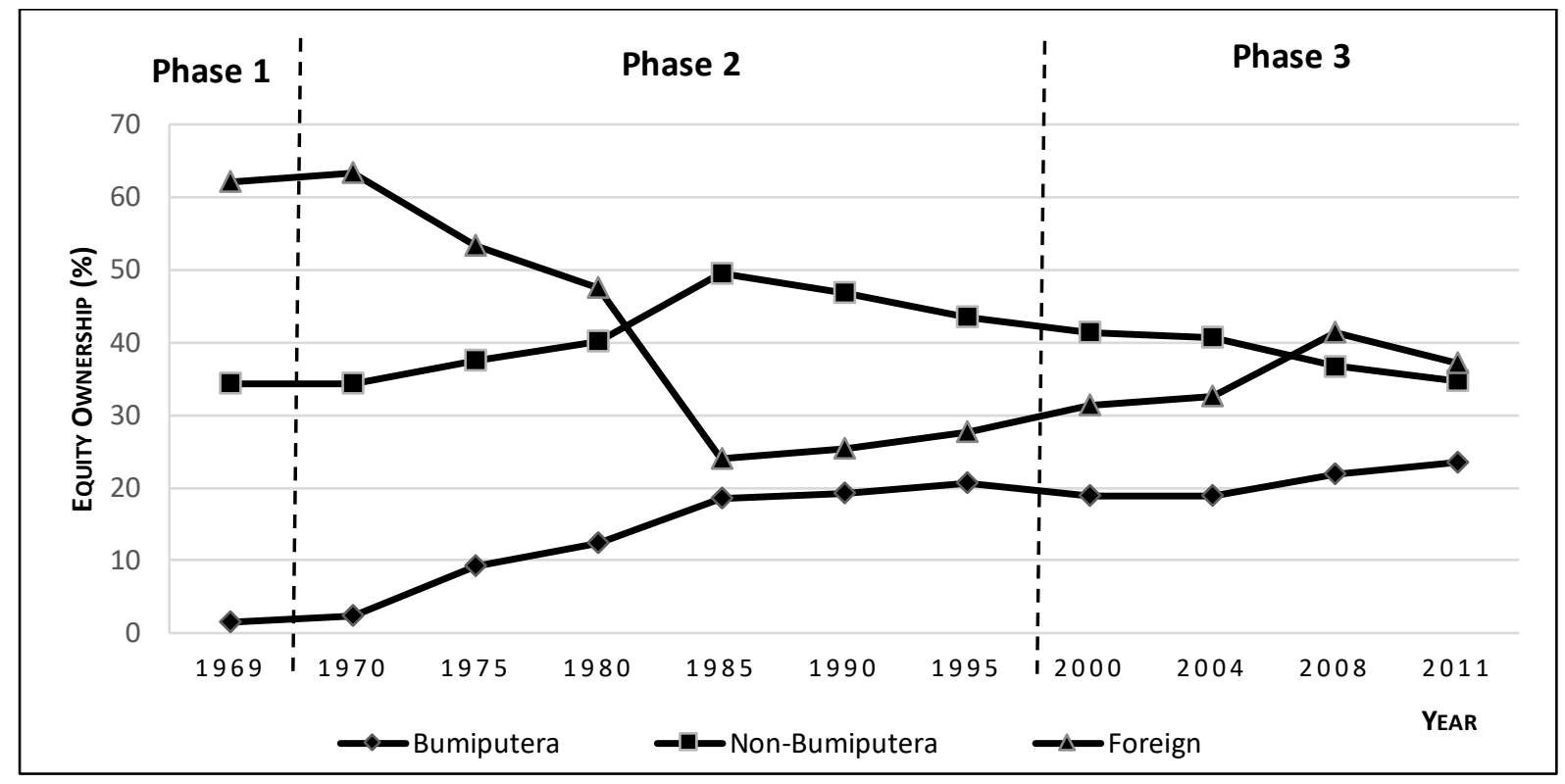

Figure 2: Equity ownership in Malaysian companies (1969-2011)

Sources:

Second Malaysia Plan, 1971-1975 (EPU, 1971, p. 40)

Third Malaysian Plan, 1976-1980 (EPU, 1976, p. 184)

Fourth Malaysian Plan, 1981-1985 (EPU, 1981, p. 61)

Sixth Malaysian Plan, 1990-1995 (EPU, 1990, p. 13)

Seventh Malaysian Plan, 1996-2000 (EPU, 1996, p.86)

Ninth Malaysian Plan, 2006-2010 (EPU, 2006, p. 356-57)

Tenth Malaysian Plan, 2011-2015 (EPU, 2011, p. 148)

Prime Minister's speech on the Eleventh Malaysia Plan, 2016-2020 (EPU, 2015, p. 7) 


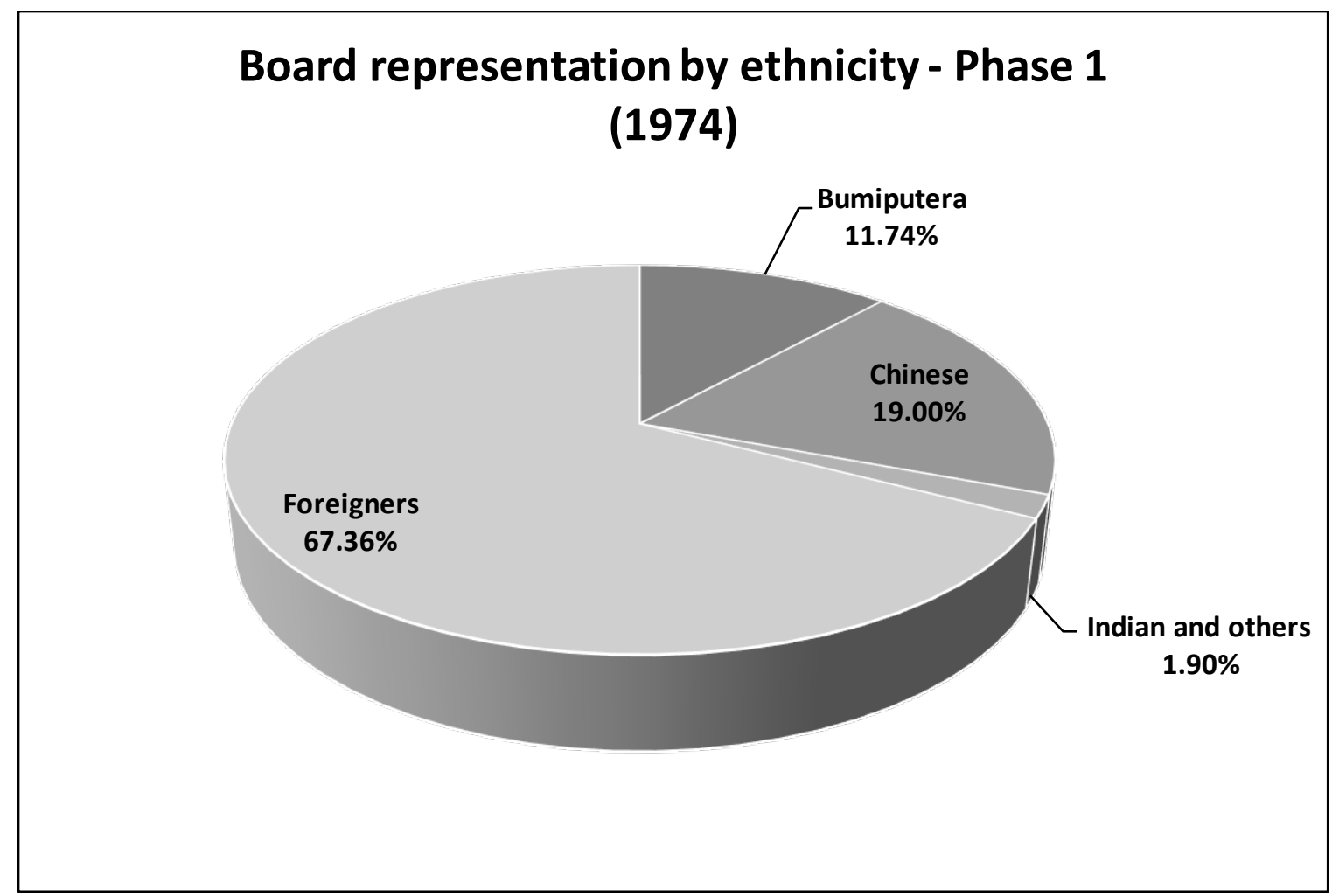

Figure 3a: Bumiputera representation on boards of directors in Kuala Lumpur Stock Exchange (now Bursa Malaysia) (1974)

Source: Data from Lim (1981) "Ownership and control of the one hundred largest corporations in Malaysia" 


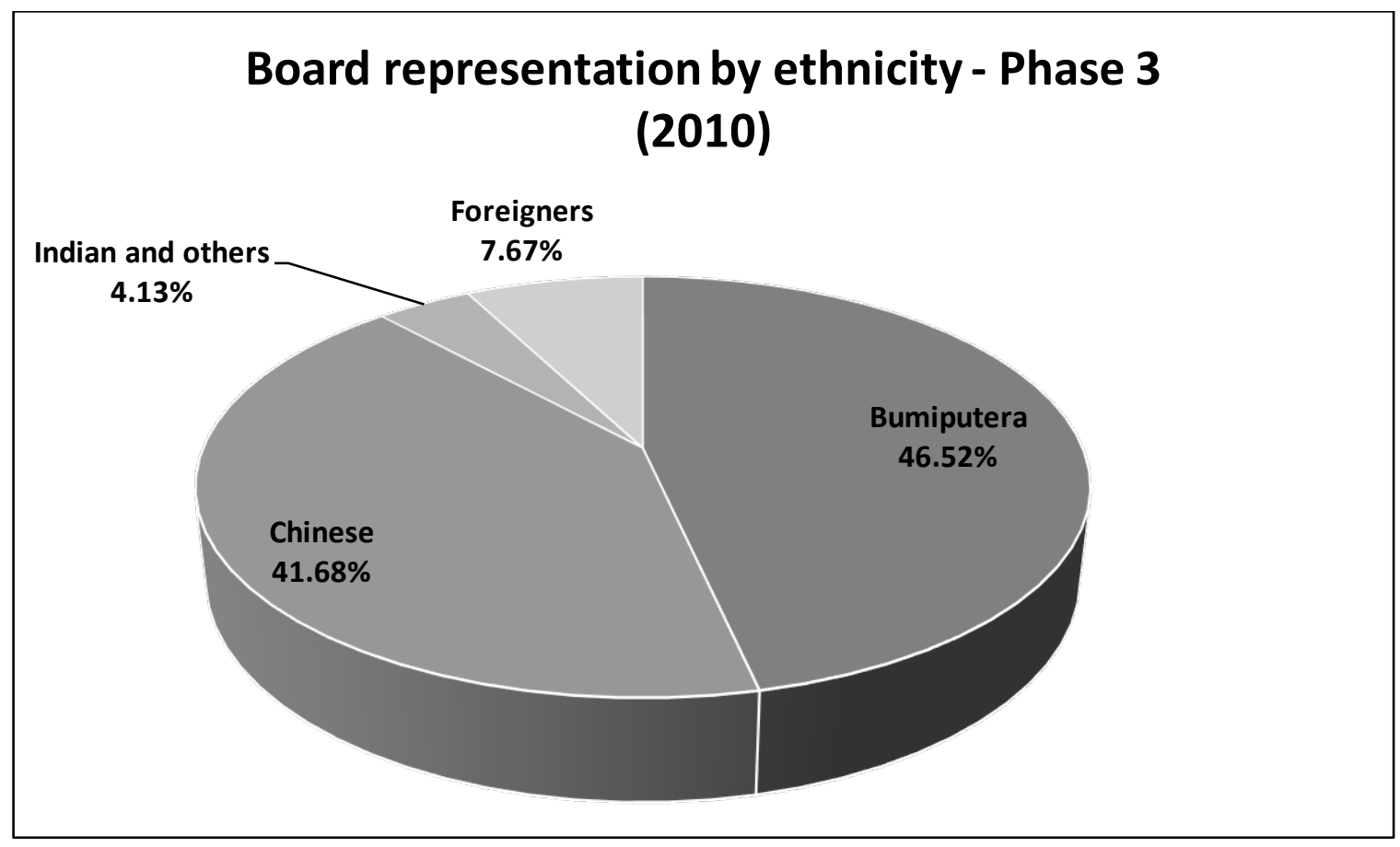

Figure 3b: Bumiputera representation on boards of directors of Top 100 Companies in Bursa Malaysia (2010)

Source: Data extracted from the annual reports of Top 100 companies listed on the FTSE Bursa Malaysia Kuala Lumpur Composite Index (FBM KLCI) 2010. 


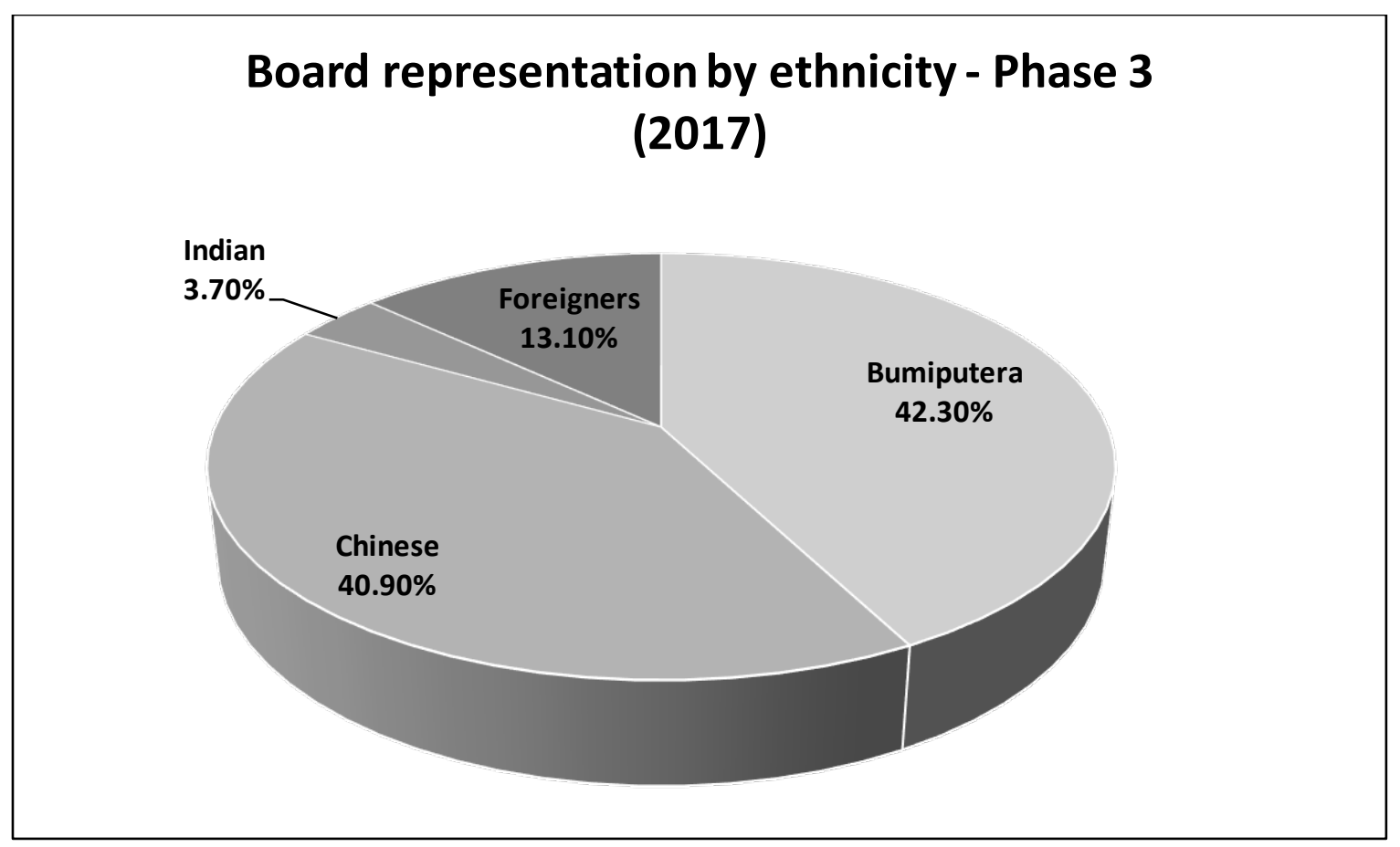

Figure 3c: Bumiputera representation on boards of directors of Top 100 Companies in Bursa Malaysia (2017)

Source: Data extracted from the annual reports of Top 100 companies listed on the FBM KLCl 2017. 
Capital Market

Masterplan (CMP)

established;

First CG ROSC by World Bank;

Major revamp of Bursa

Malaysia listing

requirement to

incorporate CG

1999

requirements;

High Level Finance

Committee on CG

established

Directors' mandatory accreditation

programme

commenced
MCCG revised -

now MCCG

(Revised) 2007;

qualification criteria

for directors

introduced, audit committee

strengthened,

internal audit

function mandated;

\section{4}

\section{Securities laws}

amended to

include whistle

blowing provision
Companies

(Amendment) Act

2007

Capital Market \& Services Act (CMSA)

\section{1}

CG Blueprint 2011

launched;

$\begin{array}{cc}\text { CMSA 2007 } & \text { Security Industry } \\ \text { amended } & \text { Dispute Resolution } \\ \text { empowering SC to } & \text { Center (SIDREC) } \\ \text { prosecute CG } & \text { established; } \\ \text { transgressions } & \\ \text { under newly } & \text { Capital Market } \\ \text { introduced sections } & \text { Masterplan 2 } \\ \text { 317A and 320A } & \text { launched }\end{array}$

MCCG 2017

released;

Companies Act

2016 came into force

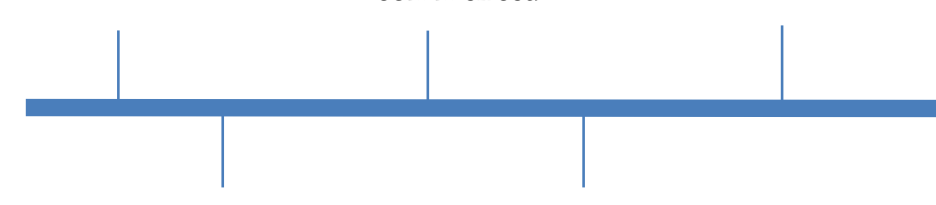

2000
MCCG 2000

introduced;

Minority Shareholder

Watchdog Group

(MSWG) established
2003

Corporate Law
Reform Committee
established by
Companies
commission of
Malaysia to spearhead
corporate law reform

Second CG ROSC

by World Bank
Bursa Malaysia Listing
Requirements amended in relation to $C G$

International CG Consultative Committee established;

Audit Oversight Board (AOB) established

Figure 4: CG development in Malaysia post-Asian crisis 
Table 1: Mechanisms to Pursue Bumiputera Interest Following the NEM 2010

\begin{tabular}{|c|c|}
\hline Date (Effort) & Notes \\
\hline $\begin{array}{l}10 \text { June } 2010 \\
\text { (Set up the Bumiputera } \\
\text { Agenda Action Council } \\
\text { or MTAB) }\end{array}$ & $\begin{array}{l}\text { To set policies and strategic direction as well as review } \\
\text { the progress and delivery of various programs and } \\
\text { initiatives pursuant to the Bumiputera Development } \\
\text { Agenda. (www.teraju.gov.my) } \\
\text { - In 2013, it was renamed the Bumiputera Economic } \\
\text { Council. }\end{array}$ \\
\hline $\begin{array}{l}1 \text { February } 2011 \\
\text { (Established the } \\
\text { Bumiputera Agenda } \\
\text { Steering Unit or Teraju) }\end{array}$ & $\begin{array}{l}\text { - A unit in the Prime Minister's Department reporting } \\
\text { directly to the Prime Minister and MTAB. } \\
\text { - Objective is to spearhead, coordinate, and drive } \\
\text { Bumiputera transformation and participation in the } \\
\text { economy and to reduce the economic gaps between } \\
\text { Bumiputera and other races. }\end{array}$ \\
\hline $\begin{array}{l}27 \text { August } 2011 \\
\text { (Establishment of RM2 } \\
\text { billion Facilitation Fund) }\end{array}$ & $\begin{array}{l}\text { - Resulting from the joint efforts of TERAJU and the } \\
\text { Public Private Partnership Unit to provide support for } \\
\text { Private Funded Initiatives of the Bumiputera. } \\
\text { - For eligible Bumiputera companies to carry out big } \\
\text { projects with minimum qualifying value of RM20 } \\
\text { million. }\end{array}$ \\
\hline $\begin{array}{l}20 \text { July } 2011 \\
\text { (Launched High } \\
\text { Performance } \\
\text { Bumiputera Companies } \\
\text { or Teras) }\end{array}$ & $\begin{array}{l}\text { - The goal is to have vibrant participation of Bumiputera } \\
\text { SMEs in the National Key Economic Areas sectors and } \\
\text { for Bumiputera SMEs to make a significant contribution } \\
\text { to the national Gross Domestic Product. } \\
\text { - Will get access to new business opportunities, } \\
\text { financing, business consultations } \\
\text { - Criteria includes Bumiputera equity of } 60 \%-100 \% \text {; } \\
\text { CEO/Managing Director must be Bumiputera; majority } \\
\text { of management teams are Bumiputera; must not be a } \\
\text { subsidiary of a GLC/Multi National Company } \\
\text { (www.teraju.gov.my) } \\
\text { - Selected } 30 \text { companies; target to have } 100 \text { companies } \\
\text { in } 3 \text { months. } \\
\text { - Priority for bidding contracts. }\end{array}$ \\
\hline 26 November 2011 & $\begin{array}{l}\text { Encompass policies and strategies to correct the } \\
\text { current imbalance in income and wealth distribution. }\end{array}$ \\
\hline
\end{tabular}




\begin{tabular}{|c|c|}
\hline $\begin{array}{l}\text { (Launched Bumiputera } \\
\text { Economic } \\
\text { Transformation } \\
\text { Roadmap) }\end{array}$ & $\begin{array}{l}\text { - Three strategic foci: reform of policy instruments and } \\
\text { rationalization of delivery system; strengthening } \\
\text { education and building capabilities; and acquiring, } \\
\text { creating or developing businesses with sufficient scale. } \\
\text { - } \quad \text { To enhance the value of Bumiputera-owned assets such } \\
\text { as unit trusts, "zakat" funds and "waqaf" land via } \\
\text { pooling them. } \\
\text { - Management of the assets by government institutions. }\end{array}$ \\
\hline $\begin{array}{l}14 \text { September } 2013 \\
\text { (Launched the } \\
\text { Bumiputera Economic } \\
\text { Empowerment Council) }\end{array}$ & $\begin{array}{l}\text { - This refers to Bumiputera economic empowerment } \\
\text { programs focusing on five areas, one of which is to } \\
\text { strengthen the Bumiputera equity ownership in the } \\
\text { corporate sector. }\end{array}$ \\
\hline $\begin{array}{l}21 \text { May } 2015 \\
\text { (Released } 11^{\text {th }} \text { Malaysian } \\
\text { Plan 2016-2020) }\end{array}$ & $\begin{array}{l}\text { - The government will undertake a five-pronged } \\
\text { approach to enhance Bumiputera Economic } \\
\text { Community to enhance wealth ownership under the } \\
\text { Plan. } \\
\text { - The government set up a target to reach } 30 \% \\
\text { Bumiputera equity by the year } 2020 \text {. RM } 47.95 \text { billion } \\
\text { have been allocated for programs towards growing } \\
\text { Bumiputera SMEs, to be implemented by the TERAJU. }\end{array}$ \\
\hline
\end{tabular}

